\title{
Time-transgressive Holocene maximum of Temperate and Mediterranean forest development across the Iberian Peninsula reflects orbital forcing
}

DOI:

10.1016/j.palaeo.2020.109739

\section{Document Version}

Accepted author manuscript

Link to publication record in Manchester Research Explorer

Citation for published version (APA):

Domingues Gomes, S., Fletcher, W., Stone, A., Abrantes, F., \& Naughton, F. (2020). Time-transgressive Holocene maximum of Temperate and Mediterranean forest development across the Iberian Peninsula reflects orbital forcing. Palaeogeography, Palaeoclimatology, Palaeoecology, 550. https://doi.org/10.1016/j.palaeo.2020.109739

Published in:

Palaeogeography, Palaeoclimatology, Palaeoecology

\section{Citing this paper}

Please note that where the full-text provided on Manchester Research Explorer is the Author Accepted Manuscript or Proof version this may differ from the final Published version. If citing, it is advised that you check and use the publisher's definitive version.

\section{General rights}

Copyright and moral rights for the publications made accessible in the Research Explorer are retained by the authors and/or other copyright owners and it is a condition of accessing publications that users recognise and abide by the legal requirements associated with these rights.

\section{Takedown policy}

If you believe that this document breaches copyright please refer to the University of Manchester's Takedown Procedures [http://man.ac.uk/04Y6Bo] or contact uml.scholarlycommunications@manchester.ac.uk providing relevant details, so we can investigate your claim.

\section{OPEN ACCESS}




\section{Palaeogeography, Palaeoclimatology, Palaeoecology Time-transgressive Holocene maximum of Temperate and Mediterranean forest development across the Iberian Peninsula reflects orbital forcing --Manuscript Draft--}

\begin{tabular}{|c|c|}
\hline Manuscript Number: & PALAEO_2020_34R2 \\
\hline Article Type: & Research Paper \\
\hline Keywords: & $\begin{array}{l}\text { maximum forest development; moisture gradient; marine pollen records; long-term } \\
\text { variability; Orbital forcing }\end{array}$ \\
\hline Corresponding Author: & $\begin{array}{l}\text { Sandra Gomes } \\
\text { Manchester University/IPMA } \\
\text { North Manchester/Lisbon, PRT UNITED KINGDOM }\end{array}$ \\
\hline First Author: & Sandra Gomes \\
\hline \multirow[t]{6}{*}{ Order of Authors: } & Sandra Gomes \\
\hline & William Fletcher \\
\hline & Teresa Rodrigues \\
\hline & Abi Stone \\
\hline & Fatima Abrantes \\
\hline & Filipa Naughton \\
\hline Manuscript Region of Origin: & Europe \\
\hline Abstract: & 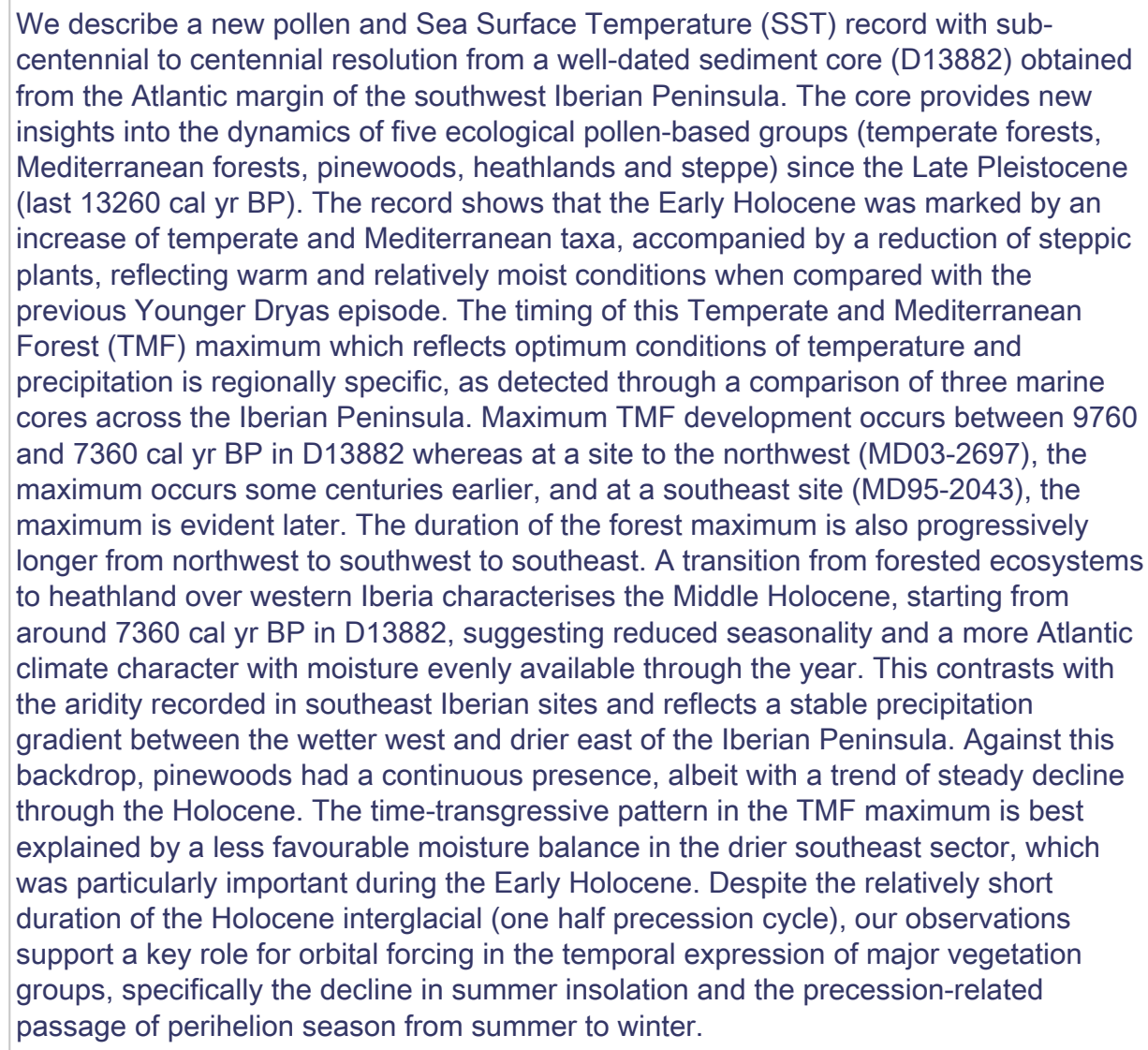 \\
\hline
\end{tabular}




\section{Highlights:}

- New pollen and SST record from SW Iberian marine for the last 13260 cal yr BP

- Time transgressive pattern of Holocene forest maximum across NW, SW and SE Iberia

- Stability of moisture gradient from NW to SE Iberia across the Holocene

- Forest to heathland transition governed by orbital forcing (precession) 
1 Time-transgressive Holocene maximum of Temperate and Mediterranean forest

2 development across the Iberian Peninsula reflects orbital forcing

3

4 Gomes S. ${ }^{a, b^{*}}$, Fletcher W.J. a, Rodrigues T. ${ }^{\mathrm{b}, \mathrm{c}}$, Stone A. ${ }^{\mathrm{a}}$, Abrantes F., ${ }^{\mathrm{b}, \mathrm{c}}$, Naughton F. ${ }^{\mathrm{b}, \mathrm{c}}$,

6 a Quaternary Environments and Geoarchaeology, Department of Geography, School of 7 Environment, Education and Development, The University of Manchester, Manchester, 8 Oxford Road, Manchester, M13 9PL, United Kingdom

$9 b^{b}$ Instituto Português do Mar e da Atmosfera (IPMA), Portuguese Institute of Sea and 10 Atmosphere, Rua Alfredo Magalhães Ramalho 6, 1495-006 Lisboa, Portugal

$11{ }^{c}$ Centro de Ciências Marinhas (CCMAR), Center of Marine Sciences, Algarve University, 12 Campus de Gambelas, 8005 - 139 Faro, Portugal

*Corresponding author: E-mail: sandra.domingues@manchester.ac.uk (Sandra Domingues Gomes); Address: Quaternary Environments and Geoarchaeology, Department of Geography, School of Environment, Education and Development, The University of Manchester, Manchester, Oxford Road, Manchester, M13 9PL, United Kingdom

Keywords: long-term variability, marine pollen records, maximum forest development, moisture gradient, orbital forcing

\section{Abstract}

We describe a new pollen and Sea Surface Temperature (SST) record with subcentennial to centennial resolution from a well-dated sediment core (D13882) obtained from the Atlantic margin of the southwest Iberian Peninsula. The core provides new insights into the dynamics of five ecological pollen-based groups (temperate forests, Mediterranean forests, pinewoods, heathlands and steppe) since the Late Pleistocene (last $13260 \mathrm{cal} \mathrm{yr}$ BP). The record shows that the Early Holocene was marked by an increase of temperate and Mediterranean taxa, accompanied by a reduction of steppic plants, reflecting warm and relatively moist conditions when compared with the previous Younger Dryas episode. The timing of this Temperate and Mediterranean Forest (TMF) maximum which reflects optimum conditions of temperature and precipitation is regionally specific, as detected through a comparison of three marine cores across the Iberian Peninsula. Maximum TMF development occurs between 9760 and 7360 cal yr BP in D13882 whereas at a site to the northwest (MD03-2697), the maximum occurs some centuries earlier, and at a southeast site (MD952043), the maximum is evident later. The duration of the forest maximum is also 
progressively longer from northwest to southwest to southeast. A transition from forested ecosystems to heathland over western Iberia characterises the Middle Holocene, starting from around 7360 cal yr BP in D13882, suggesting reduced seasonality and a more Atlantic climate character with moisture evenly available through the year. This contrasts with the aridity recorded in southeast Iberian sites and reflects a stable precipitation gradient between the wetter west and drier east of the Iberian Peninsula. Against this backdrop, pinewoods had a continuous presence, albeit with a trend of steady decline through the Holocene. The time-transgressive pattern in the TMF maximum is best explained by a less favourable moisture balance in the drier southeast sector, which was particularly important during the Early Holocene. Despite the relatively short duration of the Holocene interglacial (one half precession cycle), our observations support a key role for orbital forcing in the temporal expression of major vegetation groups, specifically the decline in summer insolation and the precession-related passage of perihelion season from summer to winter.

\section{Introduction}

The Iberian Peninsula (IP, Fig. 1a) is characterised by strong environmental gradients and considerable topographic and climatic heterogeneity, which is expressed in the diverse and sometimes surprising palaeoecological histories from different local areas (Carrión et al., $2002 ; 2010)$. This diversity can mean that it is challenging to extract general patterns at large regional scales which are needed for conceptual understanding of environmental response to climate changes and data-model comparisons (Rodríguez-Sánchez et al., 2010; Garreta et al., 2012; Mauri et al., 2015; Morellón et al., 2018). Marine pollen records, which integrate vegetation signals across extensive geographical areas, may be particularly valuable in improving the understanding of long-term patterns of vegetation development and assessing regional differences (Sánchez Goñi et al., 2017; 2018). The southwest IP has provided numerous well resolved continuous records and is an exceptional region for land-sea correlation studies. In this region, there is a history of research extending over 20 years and numerous published studies on terrestrial pollen in marine cores (Sánchez Goñi et al., 2000; 2002; 2012; 2017; Roucoux et al., 2001; 2005; Tzedakis et al., 2004; Desprat et al., 2005; 2007; 2009; Naughton et al., 2007; 2009; 2016; 2019; Margari et al., 2007; 2010; 2014; Chabaud et al., 2014; Oliveira et al., 2016; 2017; 2018). The southwest Iberian margin offers an excellent location to study the response of terrestrial vegetation to atmospheric climate changes alongside the changes within the North Atlantic marine and marine-cryosphere system that are recorded within with oceanic proxies (Shackleton et al., 2000; 2004; Sánchez Goñi et al., 2000). 
Here, we present a new pollen and Sea Surface Temperature (SST) record from marine core D13882 located on the coastal shelf off Lisbon. The particular value of core D13882 is its nearshore coastal shelf location near the Tagus outflow, effectively an intermediate geographical position between the continental Tagus basin and the previously studied deep marine cores of southwest Iberia (Fig. 1b). Supported by high-resolution radiocarbon age control, new pollen analysis was undertaken to refine the understanding of long-term regional Holocene vegetation and climate change for the southwest IP. This D13882 record is considered within a regional framework of pollen studies/reconstructions spanning $43^{\circ} \mathrm{N}$ to $36^{\circ} \mathrm{N}$ to consider potential regional gradient shifts (Fig. 1).

The Holocene represents an excellent target for developing and integrating pollen studies for the IP, allowing us to clarify the long-term dynamics of major vegetation groups with distinctive ecological and climatic affinities. Pollen records provide insights into both temperature and moisture availability, reflecting the physiological requirements of different vegetation types to winter cold and summer warmth as well the adaptation to changes in moisture availability, particularly its seasonality. Mediterranean climates have cool and temperate winters and warm and dry summers; vegetation reflects those conditions, although, in the case of forest development, the major factor is water availability (Quezel, 2000). The balance of temperate and Mediterranean (sclerophyll) elements can furthermore highlight the influence of summer drought. In western Iberia, heathlands are also a characteristic vegetation element associated with oceanic climate influence for which the long-term history remains under-explored (Andrés and Ojeda, 2002; Gil-Lopez et al., 2014). New records and their integration into a regional biogeographical framework are, therefore, essential for improving the understanding of long-term vegetation and climate changes. Despite this potential, there remain significant uncertainties for the Holocene climate with divergent trends in temperature reconstructions (Shakun et al., 2018) indicating either longterm warming (Davis et al., 2003; Davis and Brewer, 2009; Bartlein et al., 2011; Liu et al., 2014; Tarroso et al., 2016; Marsicek et al., 2018) or cooling (Cheddadi et al., 1996; 1998; Marchal et al., 2002; Brewer et al., 2007; Dormoy et al., 2009; Marcott et al., 2013; Pages2K Consortium, 2013). Refining the understanding of seasonal characteristics is essential for resolving these differences (Carré and Cheddadi, 2017). Equally, close appreciation of the ecological and biogeographical significance of vegetation types in their regional context and their translation into climatic parameters is required.

The pollen record from D13882 provides an opportunity to explore the response of vegetation composition to orbital forcing (Van der Hammen, 1971; Magri and Tzedakis, 2000; Tzedakis, 2007; Fletcher et al., 2008, Niedermeyer et al., 2010; deMenocal and Tierney, 2012; Maksic et al., 2019; Oliveira et al., 2018). These studies evidence the important influence of the precession cycle on the climate and vegetation of the 
111 Mediterranean region on long timescales. However, the implications of this impact are not 112 generally well integrated into the understanding of Holocene change, i.e. over the last half 113 precession cycle. Marine cores also provide the unique opportunity to study 114 contemporaneous changes within terrestrial and marine proxies, allowing links between atmospheric and oceanic conditions to be reconstructed. Furthermore, the Holocene is of interest as it provides the backdrop to significant changes in human history and humanenvironment interactions (deMenocal, 2001; Drysdale et al., 2006; O'Sullivan, 2008; Kuper and Kröpelin, 2006; deMenocal and Tierney, 2012; der Schrieck et al., 2007: 2008; Fyfe et al., 2015). In order to detect the influence of human activity, the natural trajectories of change associated with orbital forcing must be well understood.

The main objectives of this study are to:

- evaluate the timing and dynamics of major ecological groups (Temperate and Mediterranean Forests (TMF), pinewoods, heathlands and steppe) over the last 13260 years in the southwest IP;

- to compare vegetation histories between the northwest, southwest and southeast IP and thus evaluate leads and lags in Holocene forest development;

- to assess the influence of long-term climatic drivers across the Holocene, based on vegetation dynamics.

In particular, we seek to address the following research questions: When did the maximum development of forest occur during the Holocene in the IP? Was this development synchronous between the northwest, southwest and southeast? Is the pattern of vegetation dynamics the same for temperate and Mediterranean forest taxa?

\section{Environmental setting}

\section{[FIGURE 1]}

The study area - the southwest Iberian margin and adjacent continental landmasses of the Tagus and Sado basins - is located in the western Iberian Peninsula (IP, Fig. 1). The climate of this region is of Mediterranean-type with strong oceanic influence. At Lisbon, the mean annual temperature is $16.9^{\circ} \mathrm{C}$, and the mean annual precipitation is $690 \mathrm{~mm} / \mathrm{yr}$, with rainfall maximum from November to January and summer drought extending from June to September. The IP is affected by the North Atlantic Oscillation (NAO), a significant mode of wintertime atmospheric climate variability over the North Atlantic. The NAO influences the strength and position of the Westerlies and consequently, the precipitation over the Iberian Peninsula (e.g. Trigo et al., 2004). In summer, the region is influenced by the expansion of the Azores High to a north-eastward position (Trigo et al., 2004; Lionello et al., 2006), generating warm and dry summers. Other circulation patterns such as the East Atlantic (EA) 
pattern (Sánchez-López et al., 2016) and the Scandinavian pattern (SCAND) also impact on the climate variability over the IP (Trigo et al., 2008; Jerez and Trigo, 2013), with the positive phase of EA associated with above-average year-round surface temperatures and belowaverage precipitation across southern Europe, and the positive phase of SCAND associated with above-average precipitation over central and southern Europe.

From a bioclimatic perspective, southwest IP area represents a transitional climatic zone between the Köppen Csa classification (temperate with dry/hot summer, average temperature of the warmest month $>22^{\circ} \mathrm{C}$ ) covering the southern central plateau region and Csb (temperate with dry/temperate summer, average temperature of the hottest month $\leq$ $22^{\circ} \mathrm{C}$ ), on the northwest and the west coast of mainland Portugal (Iberian Climate Atlas, 2011). Coastal areas experience oceanic humidity which penetrates up river valleys. Thermophilous evergreen elements such as Quercus suber, Olea europaea, Myrtus communis, Phillyrea angustifolia and Pistacia lentiscus characterise lowland vegetation (Asensi and Diez-Garretas et al., 1997). At higher elevation and towards the interior, the mesomediterranean belt is characterised by forest vegetation with both evergreen (Quercus suber, Quercus rotundifolia and Quercus coccifera) and deciduous trees (e.g. Quercus faginea and Quercus robur). Pinewoods with Pinus pinea and Pinus pinaster as well as scrub with Quercus coccifera develop on sandy soils in the littoral zone. Alnus glutinosa and Salix sp. are the main riparian woodlands species. Shrub communities with Cistus spp. and Erica spp. are also widespread in fire-prone areas (Rivas-Martínez et al., 2017; Neto et al., 2009).

Marine core D13882 is located in the southwestern Iberian Shelf mud patch ( $38^{\circ} 38.07^{\prime} \mathrm{N}$; $9^{\circ} 27.25^{\prime} \mathrm{W}, 88 \mathrm{~m}$ water depth), approximately $25 \mathrm{~km}$ from the Tagus River mouth (Fig. 1b). This narrow and shallow continental shelf setting is protected against the Atlantic high energy wave regime favouring rapid and continuous deposition of sediments on the Tagus mud patch (Vis et al., 2016). The oceanographic setting is under the direct influence of two major currents, the Portugal Current (PC) and the Canary (or Azores) current (CC). These currents are southern branches of the North Atlantic Current and part of a major oceanic system which includes the North Atlantic subtropical gyre, one of the leading suppliers of the heat transport across the globe (Macdonald and Wunsch, 1996). They are dependent on the Azores High meridional displacement and the local wind-regime (Fiuza, 1984; Peliz et al., 2005). Intense river discharges (Benito et al., 2003; Naughton et al., 2007; Abrantes et al., 2009; Rodrigues et al., 2009; 2010; Vis et al., 2008) from the Tagus hydrographic basin occur mainly in the winter season (Rodrigo et al., 1999; Trigo and da Camara, 2000; Bernárdez et al., 2008; Dessandier et al., 2018).

\section{Material and methods}


A $13.61 \mathrm{~m}$ long core was retrieved using a British Oceanography long-piston coring system during the cruise Discovery 249 cruise in 2000 onboard the R/V Discover (Weaver, 2003) (Fig. 1b). A total of 25 AMS ${ }^{14} \mathrm{C}$ dates were obtained at the Leibniz Laboratory at Kiel University (KIA) and the National Ocean Sciences Accelerator Mass Spectrometer (NOSAMS) facility at Woods Hole Oceanographic Institution (WHOI), mainly from mollusc and mixed benthic foraminifera shells. The age-depth model of core D13882 was derived using a Bayesian approach in Oxcal program version 4.2 (Fig. 2; full details in Naughton et al., 2019). The core spans the last 13260 cal yr BP.

\subsection{Palynology}

196

A total of 143 samples for pollen analysis were collected at intervals varying between 5 and $10 \mathrm{~cm}$ (time resolution of $\sim 89$ years on average). The extraction of pollen and spores was performed following the protocol used at EPHE, Bordeaux University (Castéra, M-H., n.d.). The samples were subjected to chemical digests of cold $\mathrm{HCl}$ (at $10 \%, 25 \%$ and $50 \%$ ) and cold HF (at $40 \%$ and $70 \%$ ) to eliminate carbonates and silicates respectively and sieving through $10 \mu \mathrm{m}$ nylon mesh screens (Heusser and Stock, 1984). A known number of exotic Lycopodium spores in tablet form were added to each sample to permit calculation of pollen concentrations (Stockmarr, 1971). We used a mixed mounting medium composed of phenol and glycerol $(1 \% \mathrm{w} / \mathrm{v})$ to mount the remaining residue. This step allows partial mobility of grains on the slides, which assists in the identification of the pollen and spores. Pollen counts were undertaken using a transmitted light microscope at $x 400$ and $x 1000$ (oil immersion) magnifications. To assist pollen identification, we consulted several identification keys (Faegri and Iversen, 1989; Moore et al., 1991), photographic atlases (Reille, 1992; 1995) and the Mediterranean modern reference collection from the project SWIRL (Algarve University). Also, for the identification of Ericaceae and Cistaceae pollen types, we used the special identification keys from Mateus (1992) and Queiroz (1999), respectively. On average, pollen was counted to reach the main pollen sum of at least 150 grains (mean= 187 and standard deviation (STDV)= 25.5); an average of 426 pollen and spores (STDV = 154) characterises the total pollen sum. The main pollen sum calculation excluded Pinus, Cedrus, wetland species and aquatic plants, Pteridophyta, spores and indeterminable pollen. To obtain statistically reliable pollen spectra, we also counted a minimum of 20 taxa in each sample (mean=32.11, STDV=4.37) or a minimum of 100 Lycopodium spores (mean=364.35, STDV=306.64) (McAndrews and King, 1976; Heusser and Balsam, 1977). Pinus pollen is considered to be overrepresented in marine deposits (Heusser and Balsam, 1977; Turon; 1984; Rochon et al., 1994), including those from the western Iberian margin (Naughton et 
al., 2007), and is therefore excluded from the main pollen sum. Because D13882 is close to

223 the coast and the Tagus estuary we excluded all the potential components of coastal wetlands: Cyperaceae, Hypericum, Lythrum, Pedicularis, Poaceae, Polygonaceae, Polygonum amphibium type, Polygonum bistorta type, Polygonum persicaria type, Ranunculaceae, Sparganium, Thalictrum, Typha latifolia, Typha-Sparganium and Urticaceae. Individual pollen percentages of each taxon not included in the main pollen sum were calculated based on the main pollen sum plus the taxon count.

Pollen diagrams were plotted using PSIMPOLL 4.27 (Bennett, 1994; 2009). The number of statistically significant pollen assemblage zones was determined by Constrained Cluster Analysis by Sum Squares (CONISS) based on a dissimilarity matrix of Euclidean distances with pollen taxa $\geq 1 \%$ (Grimm, 1987), yielding seven main pollen zones (D13882-1 to D13882-7).

Five ecological pollen-based groups (TF - Temperate forest, MF - Mediterranean forest, PIN - pinewoods, ERI - heathland and STE - steppe/xerophytic/semi-desert plants) were created to understand the main vegetation changes through time (Fig. 3) (Fletcher et al., 2010). The TF group includes deciduous Quercus, Acer, Betula, Cannabis, Humulus, Carpinus, Castanea, Fraxinus excelsior type, Hedera helix, Hippophae, Ilex, Juglans, Myrica and Vitis; MF is composed of evergreen Quercus, Quercus suber type, Arbutus unedo type, Buxus, Daphne, Jasminum, Ligustrum, Myrtus, Olea, Phillyrea, Pistacia, Rhamnus, Rhus; PIN comprises Pinus pollen only; ERI includes all the Ericaceae including Calluna sp. and the STE group includes Amaranthaceae (Chenopodiaceae), Artemisia and Ephedra. Since Iberian forests may comprise a mixture of temperate and Mediterranean elements, we also discuss the combined TMF (Temperate and Mediterranean forest), which represents the sum of the TF and MF ecological groups as defined above.

\section{[FIGURE 3]}

\subsection{Sea Surface Temperatures (SST) records}

Alkenone-derived sea surface temperatures (SST), quantified on 240 samples (every 2 to $5 \mathrm{~cm}$ of core depth), were published in Rodrigues et al. (2009; 2010). Here we report new SST data with an extra 55 samples, allowing an increase in the time resolution between two consecutive samples (43 years on average). Extraction methods followed Villanueva and Grimalt (1996), and Villanueva et al. (1997; 1997a). SST reconstruction is based upon the relative composition of $\mathrm{C}^{37}$ unsaturated alkenones using the $\mathrm{Uk}^{\mathrm{k}_{37}}$ index (Prahl and Wakeman, 1987) and calibrated using the equation defined by Müller et al. (1998) with an 


\section{Results}

The palynological record of D13882 is rich and diverse with very well preserved pollen and spores ( 144 different pollen/spores types were identified) (Figure 3). We distinguish seven pollen zones based on the main groups (Fig. 4), which are detailed in Table 1 and Figure 3. In summary, the record reveals major changes in vegetation composition/climate in the southwest IP:

Pollen zone D13882-1 (13260 - 12890 cal yr BP) is characterised by open woodland and pinewoods reflecting relatively warm and moist environments attributed to the end of the Bolling-Allerod (B-A) period. D13882-2 (12890 - 11790 cal yr BP) is marked by a slight reduction of TF and expansion of STE, reflecting cooling and drying in southwest Iberia during the Younger Dryas (YD) (continental counterpart of the Greenland Stadial 1- GS1). D13882-3 (11790 - 9760 cal yr BP) shows the recovery of the TF and MF, a decrease in STE contrasting with the increase of the carr and aquatic taxa (maximum values of Isoetes undiff.) suggesting a climatic warming and increase in moisture availability in the Early Holocene when compared with the previous pollen zone. D13882-4 (9760 - 7360 cal yr BP) reveals the maximum development of TF as well MF, reflecting optimum warmth and wettest conditions in southwest IP. D13882-5 (7360 - 4770 cal yr BP) is marked by strong forest contraction (TF and MF) and expansion of ERI (mostly composed of E. arborea, E. australis and E. umbellata pollen types), suggesting more oceanic conditions with reduced seasonality during the Middle Holocene. D13882-6 (4770 - 1970 cal yr BP) is characterised by the further establishment and dominance of ERI and the decline of PIN, indicating a relative winter dryness but persisting annual moisture availability during the transition to the Late Holocene. D13882-7 (1970 - 640 cal yr BP) marks the decline of almost all ecological groups except the heathland, reflecting an expansion of open ground communities with anthropogenic indicators during the last $2000 \mathrm{yr}$.

\subsection{Sea surface temperatures on the southwest Iberian Shelf}

The end of the B-A, $13260-12890$ cal yr BP, is characterised by SSTs of about $11^{\circ} \mathrm{C}$ (Fig. 4a). A cooling episode of $\sim 3^{\circ} \mathrm{C}$ marks the YD/GS-1 between 12890 and 11790 cal yr BP in southwest Iberian shelf (core D13882) (Fig. 4a). A sudden warming episode (in less than 100 years), of $\sim 8^{\circ} \mathrm{C}$ in core D13882 record marks the onset of the Holocene. The maximum Holocene sea surface temperature of $19.5^{\circ} \mathrm{C}$, is observed at around $11400 \mathrm{cal}$ yr BP. The 
sea surface conditions in the southwest Iberian shelf along the Holocene are fairly stable during the Holocene (Fig. 4a). However, a long-term and gradual decrease of SST is detected across the Holocene $\left(\sim 5^{\circ} \mathrm{C}\right)$, with a maximum $\left(\sim 19.5^{\circ} \mathrm{C}\right)$ during the Early Holocene and a minimum of $14.6^{\circ} \mathrm{C}$ at $640 \mathrm{cal}$ yr BP.

\section{Vegetation and environmental history of southwest IP}

\subsection{Temperate and Mediterranean Forest}

\section{[FIGURE 5]}

The lowermost few samples reflect the regional presence of open woodland and pinewoods which is characteristic of the B-A/Greenland Interstadial $1(\mathrm{Gl}-1)$ in the southwestern IP (Fletcher et al., 2007; Chabaud et al., 2014; Oliveira et al., 2018). The transition to the YD is marked by a subtle decrease of TMF, mainly MF (Fig. 4c and e), reflecting a cooling episode with moderately drier conditions. However, the modest abundances of TMF (Table 1, Fig. 3 and 4c) suggest that some moisture was still delivered to the region during the YD/GS-1 interval (Naughton et al., 2019). A rapid increase in TMF, both TF and MF, marks the onset of the Holocene (11700 cal kyr BP) (Fig. 4c, d and e), suggesting a response to climate warming and increase in moisture availability without lags, due to the proximity to glacial refugia for temperate and Mediterranean taxa (Figueiral and Terral, 2002; García-Amorena et al., 2007; López de Heredia et al., 2007). However, the maximum expansion of TMF occurs later, between 9760 and 7360 cal yr BP in the D13882 record, suggesting that optimum climate conditions for forest development occurred almost $2000 \mathrm{yr}$ after the beginning of the Holocene (Fig. 4c, 5b and 6c). In particular, the maximum expansion of deciduous oak (TF, Fig. 3a and 4c) requires both high temperatures and winter precipitation (Fletcher et al., 2010; Naughton et al., 2019) while evergreen oak, Olea and Pistacia (MF, Fig. 3a) reflects not only high temperatures and winter precipitation but also, intense summer drought (Costa et al., 2012; Espírito-Santo et al., 2017). Similar forest composition is detected in both continental (LSA, Santos and Sánchez Goñi, 2003) and marine (U1385A, Oliveira et al., 2018; MD95-2042, Chabaud et al., 2014; SU81-18, Turon et al., 2003) records from the same region (Fig. 1).

In the northwest and central IP, maximum TMF (mainly TF) development seems to have occurred before $\sim 10000$ cal yr BP (Fig. 5 and 6b). In the marine core MD03-2697 (northwest record) the TF peaks before $11000 \mathrm{cal}$ yr BP (Fig. 6b), almost simultaneous with maximum insolation at the Northern Hemisphere $\left(65^{\circ} \mathrm{N}\right)$ (Naughton et al., 2016). Within age-model uncertainties, other records from continental sites of the north IP (e.g. Tunner and Hannon, 1988; Penalba, 1994; Allen et al., 1996; López-Merino et al., 2012) and the central IP (van der Brink and Janssen, 1985; van der Knaap and van Leeuwen, 1995; Morales-Molino et al., 
2013), are consistent with an early maximum forest development, between $\sim 11000$ to 10000 cal yr BP. The climatic conditions (warm temperature and high moisture availability) at the northern sites sustained the TF ecosystem until its decrease between 8000 and $6000 \mathrm{cal} \mathrm{yr}$ BP (e.g. Naughton et al., 2007; López-Merino et al., 2012; Morales-Molino and GarcíaAntón, 2014). This suggests that warm temperature and moisture availability promoted the maximum forest development in the wetter northwest IP sector from the onset of the Early Holocene.

In contrast, the southeast Iberian margin cores (MD95-2043, Fig. 6d and ODP-976) are marked by a later and longer duration of high TMF abundances between $~ 10500$ and 5500 cal yr BP, with a more significant MF component, with its maximum peak values detected between $\sim 9000$ to 7500 cal yr BP (Fig. 5b and 6d) (e.g. Fletcher and Sánchez Goñi, 2008; Combourieu-Nebout et al., 2009; Ramos-Román et al., 2018). We note that the mesophytic forest maxima in the southeast of IP recorded from the Siles, Sierra de Baza and Padul pollen records fall within the same broad time window from $\sim 10500$ to 5500 cal yr BP (Carrión, 2002; Carrión et al., 2007; Ramos-Román et al., 2018).

The delayed response of TMF maximum expansion between north and south of IP is likely the result of a reduced moisture balance to the south, especially lower winter precipitation (Fig. 5 and 6). This deficit in winter precipitation in the south further supports the reduced expansion of TF in the south when compared with the north and central IP, as previously suggested by several authors (Combourieu-Nebout et al., 2009; Fletcher et al., 2010; Chabaud et al., 2014). In contrast, the high expansion of MF in the south and central IP reflects generally drier conditions and particular influence of intensified summer drought (Fig. 5 and 6 ). This region presents the lowest values of forest development $(<60 \%$ of maximum), possibly representing a patchy and more open Mediterranean ecosystem. The influence of both the Atlantic in the southwest and the Mediterranean in the southeast controls the moisture distribution in the IP (Gimeno et al., 2010; Peyron et al., 2017) (evidenced in the present-day precipitation patterns, Fig. 1a).

\subsection{Heathlands}

The TMF retreat at around 7360 cal yr BP coincides with a stepwise expansion of ERI in southwest IP (core D13882, Fig. 4d). Heathlands prefer evenly distributed precipitation through the year (Ojeda et al., 1998) as well as high atmospheric humidity. In particular, Erica arborea is known to have affinities with a more temperate, less seasonally-contrasted climate, i.e. a Mediterranean climate with an Atlantic "fidelity" (de Benito, 1948), exhibiting a positive correlation with rainfall and a negative correlation with water stress (Ojeda et al., 1998) and an ecological preference for persistent atmospheric humidity (Jalut et al., 2000; 
Whittaker and Fernandez-Palacios, 2007). In core D13822, the abundance of E. arborea, E. australis and E. umbellata pollen types within the ERI group (Fig. 3a) supports the development of characteristic heathlands which extend northwards along the Atlantic façade of Europe (Ojeda et al., 1998; Rivas-Martínez et al., 2017).

Either a steady or a stepwise, expansion of heathlands from the Middle Holocene has also been noticed in several marine and terrestrial records from central (e.g. Lagoa Comprida 2: van der Brink and Janssen, 1985; Charco da Candieira: van der Knaap and van Leeuwen,1985; El Maillo: Morales-Molino et al., 2013) and southwest IP (e.g. Lagoa Travessa: Mateus, 1989; 1992; Lagoa da Albufeira: Queiroz, 1989; 1999; LSA: Santos and Sánchez Goñi, 2003; SU81-18: Turon et al., 2003; Paul do Boquilobo: Vis et al., 2010; MD95-2042: Chabaud et al., 2014; U1385A: Oliveira et al., 2018). Maximum heathland expansion occurred during the Late Holocene, although the timing in the northwest and southeast was different. In the north, heathlands increase slightly after $\sim 6000-5000$ cal yr BP and attain moderate expansion later at $\sim 3500$ cal $\mathrm{yr} B P$ in the northernmost and mountainous areas (Sanabria: Turner and Hannon, 1988; Quintanar de la Sierra 2: Penalba, 1994; Lagoa de Ajo: Allen et al., 1996; PRD-4: López-Merino et al., 2012; Ayoó de Vidriales: Morales-Molino and García-Antón, 2014). Interestingly, the northwestern Iberian margin record, MD03-2697 (Fig. 5), shows a steady development of heathland starting around 7500 cal yr BP (Naughton et al., 2007; 2016). Pollen included in this marine record reflects the vegetation of the Douro hydrographic basin (Naughton et al., 2007; 2016) and may indicate therefore a more regional and integrated signal which can be amplified by the persistence of nearby littoral heathland ecosystems. The southeast sector shows a moderate/low development of the heathland after $\sim 7000-6000$ cal yr BP (e.g. Carrión and van Geel, 1999; Carrión et al., 2010; Fletcher et al., 2007; Fletcher and Sánchez-Goñi, 2008; ComborieutNebout et al., 2009; Ramos-Román et al., 2018) (Fig. 6d).

Over the last $6 \mathrm{kyr}$, the dominance of ERI and low MF in the southwest, in contrast with the relatively high MF and high STE vegetation in the southeast (Fig. 5c, $5 d$ and 6) demonstrates a gradient of temperature and moisture availability, specifically of moderate temperature and moisture availability in the west and high temperature and low precipitation in the east (e.g. Carrión and van Geel, 1999; Carrión et al., 2010; Fletcher et al., 2007; Fletcher and Sánchez Goñi, 2008; Comborieut-Nebout et al., 2009; Ramos-Román et al., 2018).

\subsection{Pinewoods}

The D13882 pollen record reveals a long-term reduction of PIN between the YD/GS-1 and the Late Holocene (Fig. 3a and 4b). The same pattern was detected elsewhere in both 
terrestrial and marine pollen records (e.g. Lago de Ajo: Allen et al., 1996; CM5 Guadiana: Fletcher et al., 2007; MD03-2043: Naughton et al., 2007; MD95-2042: Chabaud et al., 2014; Desprat et al., 2015). Two main groups of pines are important today in the Tagus basin: montane pines ( $P$. sylvestris - Scots pine and $P$. nigra - European black pine) and with Mediterranean $(P$. pinea - stone pine, $P$. pinaster - cluster pine and $P$. halepensis - Aleppo pine) species (Barbero et al. 1998; EUROFORGEN, 2009). The dominance of Pinus sp. during the last glacial-interglacial transition (LGIT) in the D13882 record may reflect the presence of montane species which persisted in the lower and middle slopes of high mountains of the Tagus basin (Garcia-Amorena et al., 2007). The montane species are more competitive in harsh climatic conditions, during which substantial seasonal changes from winter frost to hot summers are present; these species are forest formers and pioneer species in montane levels, growing in siliceous and well-drained soils. The coldest phases of GS-1 are marked by a slight pine decline (Naughton et al., 2019) (Fig. 3a). However, the still high percentages of this taxon may reflect the presence of montane species adapted to cold winters and high seasonality.

Terrestrial pollen and charcoal records that differentiate to species-level allow us to explore plausible species patterns. In the central-western IP, the presence of Pinus sylvestris pollen grains (inferred from morphometric analyses) during the LGIT at Charco da Candieira ( 12400 to 11300 cal yr BP) as well as at Lagoa do Golfo (Queiroz, 1999; 2004) supports the idea of the presence of montane species (van der Knaap and Leeuwen, 1995). Indeed, Pinus sylvestris subsisted in central Portugal before the LGIT, during the Last Glacial Maximum (LGM) (Figueiral and Carcaillet, 2005, García-Amorena et al., 2007).

The slight decline in Pinus sp. during the Early Holocene, detected in core D13882, may reveal a decrease of montane species and the takeover by Mediterranean pinewoods and temperate forests in the Tagus watershed, as a result of a shift to warmer and wetter conditions, and to more fertile organic soils (García-Amorena et al., 2007). Although the morphometric analysis was not performed in this study specifically, the transition from montane to Mediterranean pinewoods is supported by several studies from the nearby continent (Queiroz, 1999; Fletcher, 2005). This decline of montane species ( $P$. sylvestris) is detected also around 9500 cal yr BP at central-western IP (Buraca Grande) (Figueiral and Carcaillet, 2005). The Mediterranean species are frost-sensitive and do not survive in winter temperatures below $6^{\circ} \mathrm{C}$ (Polunin and Walters, 1985).

The Middle Holocene in the southwest IP is marked by a steady decrease of Pinus sp. in the D13882 (Fig. 4b) core as well as in all Iberian margin (IM) marine and most terrestrial records (van Leeuwarden and Jansen, 1985; Mateus, 1989; 1992; Queiroz, 1989; 1999; van der Knaap and van Leeuwen, 1995; Gómez-Orellana et al., 2001; Fletcher et al., 2007). A continuous long-term decrease of Pinus sp. is observed during the Late Holocene, in 
particular, the minimum in pinewoods during the last 1 kyr (Fig. 4b), which may be exacerbated by human activities including logging, grazing and fire (Connor et al., 2012).

\subsection{Holocene climate drivers for regional patterns of forest development}

\section{[FIGURE 6]}

The direct comparison between SST and TMF from core D13882 shows a delay of 1000 yr between maximum SSTs in the Iberian margin and the maximum of forest expansion (climate optimum for arboreal taxa on the continent) in the southwest Iberian Peninsula (Fig. 4a and 4c). The same lag between marine and the terrestrial response has been detected in other marine records from the same region (MD95-2042: Chabaud et al., 2014) as well as in the southeast (MD95-2043: Fletcher and Sánchez Goñi, 2008; ODP 796: Combourieu-Nebout et al., 2009). In contrast, the northwest site (MD03-2697) does not show any delay between SST and TMF, which both attain their maximum $700 \mathrm{yr}$ after the onset of the Holocene (Naughton et al., 2007; 2016). Although the Northern Hemisphere insolation maximum occurred near the onset of the Holocene (11700 cal yr BP) (Berger, 1978), the warmest sea surface conditions in the Iberian margin were reached between 11000 - 10500 cal yr BP (e.g. Cacho et al., 1999; Rodrigues et al., 2009; Chabaud et al., 2014; Naughton et al., 2016). The delayed response between insolation and SST could be the result of the impact of the sudden and short-lived release of meltwater, from the remaining ice sheets, in the northern latitudes of the North Atlantic (e.g. Renssen and Isarin, 2001; Praetorius et al., 2008).

There is a regionally specific pattern in the timing (and ecosystem/ forest composition) of the maximum forest development. This spatial pattern reflects a spatial gradient (consistent through time) of increasing moisture stress from the northwest to southeast. The delayed response of TMF maximum expansion between north and south of IP is likely the result of a lowering in precipitation/moisture balance in the south, associated with more intense aridity during the first millennium (Fig. 5 and 6). The lower moisture balance in the south further supports the reduced expansion of TF in the Mediterranean region when compared with the north and central IP, as previously suggested by Combourieu-Nebout et al. (2009), Dormoy et al. (2009), Fletcher et al. (2010) and Chabaud et al. (2014).

In contrast, the high expansion of MF in the south and central IP when compared to the north might be likely the result of intensified summer drought in this area (Fig. 5 and $6 \mathrm{~d}$ ). The spatial distribution of precipitation is also evident in the expansion of MF and steppe plants (seasonal drought or aridity tolerant groups), which show a consistent pattern of lowest to highest abundances in a northwest to southeast direction across each 2000 to $3000 \mathrm{yr}$ timestep in the Holocene (Fig. 5). The Early Holocene spatial precipitation gradient is quite 
481 similar to that documented for IP under present-day conditions (e.g. Serrano et al., 1999; 482 Gimeno et al., 2010; Trigo et al., 2013) or even in the past during episodes with very 483 different boundary conditions (such as during Heinrich Stadials and the Younger Dryas: Kageyama et al., 2005; Naughton et al., 2019). The delayed response of TMF, associated with a deficit in precipitation in the south, especially in the southeast, could likely also result from other particular baseline climate conditions that affected the Early Holocene, such as the persistence of Northern Hemisphere ice sheets as previously proposed by Desprat et al. (2013). The extent of the ice sheet can exert control on the atmospheric circulation over the North Atlantic region (Montero-Serrano et al., 2010). In particular, the persistence of the Fennoscandian Ice sheet up to $9 \mathrm{kyr}$ could have a significant impact on the response of the European hydroclimate to insolation forcing by sustaining the North Atlantic storm track in a relatively southern position, although rarely reaching the Mediterranean region (Desprat et al., 2013).

Other processes, such as evaporation, could also explain the reduction in moisture balance in the south during the Early Holocene as proposed by Tzedakis (2007) and reflected in eastern IP lake level records (Morellón et al., 2018). The high summer insolation at $65^{\circ} \mathrm{N}$ and the existing thermal gradient between the north and south of Iberian margin during the Early Holocene (Salgueiro et al., 2014), with maximum temperatures to the south, could have favoured enhanced evaporation and therefore reduced moisture balance in the Mediterranean region (e.g. Ramos-Román et al., 2018). Gradual summer cooling over the Holocene may have promoted the longer extension of the forest maximum in the SE through the Middle Holocene, as evaporative stress reduced. The SW region experienced an intermediate state between the short-lived, high-amplitude temperate forest development (northwest region, Fig. 6b) and the lower-amplitude and longer duration persistence of the Mediterranean woodlands (southeast region, Fig. 6d).

The duration of the Holocene forest maximum is regionally specific, suggesting the progressive crossing of regional thresholds in response to gradual climate change. A marked decline in forest (TMF, including both TF and MF) occurs in the D13882 record at around 7360 cal yr BP with no subsequent recovery during the Middle and Late Holocene, suggesting a subtle but important decline in seasonality; the ecological preference of the heathlands supports a shift towards greater moisture availability throughout the year in this region (Fig. 4d and 5). In the northwest, a similar major decrease of TMF occurred earlier at around $8000 \mathrm{cal} \mathrm{yr} \mathrm{BP}$ due to a more sensitive response to the combined effects of decreasing insolation, summer temperature and precipitation (Thatcher et al., 2020). In contrast, in the southeast IP, TF reduced while MF persisted associated with minor

516 increases in both steppe plants and heathlands during the Middle and Late Holocene (e.g.

517 Fletcher et al., 2007; Fletcher and Sánchez Goñi, 2008; Comborieut-Nebout et al., 2009; 
518 Ramos-Román et al., 2018) (Fig. 5 and 6d). This pattern suggests a lower moisture balance 519 in the Mediterranean region that persisted across the Middle and Late Holocene (Fig. 5 and 520 6). Similar thermal and precipitation gradients occurred between the Atlantic and 521 Mediterranean sides of southern IP in other periods, such as in the previous interglacial 522 (Sánchez Goñi et al., 2002). This long-term perspective furthermore highlights the resilience 523 of Mediterranean vegetation in the southeast sector compared with the other regions, 524 showing a comparatively stable persistence of the forest composition and cover which contrasts with marked changes from TF to ERI observed in the western IP (Fig.5).

A dominance of heathlands is associated with cooler conditions and is also favoured by low seasonal moisture contrast (Andrés and Ojeda, 2002). The increase in heathlands parallels the changing precession index (Fig. $6 \mathrm{a}$ - black line) and the transition of perihelion season to $\mathrm{NH}$ winter. Previous studies of glacial and interglacial periods across the last 450,000 years have shown that the expansion of heathlands was highest under precession maxima ( $\mathrm{NH}$ summer insolation minimum) and lowest under precession minima $(\mathrm{NH}$ summer insolation maximum) (Magri and Tzedakis, 2000; Roucoux et al., 2006; Margari et al., 2007, 2014; Fletcher and Sánchez Goñi, 2008; Chabaud et al., 2014; Oliveira et al., 2016; 2017). This long Quaternary perspective provides important counter-balance to the view that Holocene heathlands are a cultural landscape resulting from anthropogenic action (e.g. Andrés and Ojeda, 2002; Connor et al., 2012; Amigo et al., 2017). It is important to recognise that the expansion of heathlands is not restricted to the Holocene; genetic studies reveal their presence in the African mountains since the Pliocene, and the IP is recognised as a late Cenozoic refuge for Erica arborea, in particular (Désamoré et al., 2011). Recently, studies in the Gibraltar heathland ecosystem support the natural origin of these landscapes due to its floristic richness and high levels of endemics (Gil-Lopez et al., 2014).

While heathland increased with perihelion during the NH winter (Fletcher and SanchezGoni, 2008), the evolution of forest cover (and its composition) in the analysed IP records (Fig. 6c) parallels the decrease in summer insolation $\left(65^{\circ} \mathrm{N}\right)$ (Fig. 6a) with maximum TMF development generally around perihelion during the $\mathrm{NH}$ summer. We note however that the maximum development for the northwest and southwest IP occurred earlier (Fig. 6 b and c) in the precession cycle (perihelion passage in June to July) compared with the southeast sector with a maximum between 9000 to 7500 cal yr BP (July to August perihelion, Fig. 6d) and still high forest values extending to $5000 \mathrm{cal}$ yr BP (September perihelion). Magri and Tzedakis (2000) proposed, based on observations of long pollen records from the Mediterranean, that maximum development of interglacial forests occurred with perihelion during late $\mathrm{NH}$ summer to $\mathrm{NH}$ autumn (September). Hence we observe the weakening of 553 this classic precession pattern at the Mediterranean to temperate climate region boundary, reflecting distinct regional responses to orbital forcing. 
We infer that declining summer insolation at $65^{\circ} \mathrm{N}$ reduced the land-sea temperature contrast in this region and reduced the seasonality of the climate over the Iberian margin during the Holocene. Numerical coupled atmosphere-ocean circulation climate models demonstrate that changes in forcing associated with the precession cycle influence can affect the seasonal amplitude of both temperature and precipitation regimes in the Mediterranean region, supporting stronger seasonality during the Early Holocene (Brayshaw et al., 2011; Bosmans et al., 2015). Therefore, we consider the evolution (gradual reduction in seasonal amplitude) of temperature and precipitation associated with the precession cycle as a likely driver for the decline of temperate and Mediterranean forests during the Holocene and the expansion of heathlands in the west IP (Fig. 5). In particular, enhanced delivery of winter precipitation into the Mediterranean region is modelled as part of a southward shift of wintertime precipitation over Europe during the Early Holocene ( $8 \mathrm{ka}$ and 6 ka simulations vs pre-industrial; Brayshaw et al., 2011) leading to a higher total (annual) precipitation as documented by recent speleothem research in western Portugal showing a precipitation maximum at $9 \mathrm{ka}$ (Thatcher et al., 2020). Stronger seasonal temperature cycles are also simulated for the Early Holocene, consistent with insolation forcing (Brayshaw et al., 2011), with summer dryness enhanced by stable high temperatures and low relative humidity (Bosmans et al., 2015). In contrast to a reduction of winter precipitation, modest increases in summer precipitation favouring the development of heathlands along the Atlantic margin may have been generated by local convection (land-sea breezes, advective fogs - e.g. Daveau, 1980, summer storms) consistent with simulated atmospheric instability and higher relative humidity within the cooler precession maximum scenario (Bosmans et al., 2015).

Furthermore, superimposed on the long-term trends discussed here, climatic variability related for example to westerly position, NAO dynamics and Mediterranean storm activity may have impacted vegetation cover and composition (Fletcher et al., 2013; Di Rita et al., 2018). Centennial to millennial-scale atmospheric dynamics may be evident, for example, in the step-like decreases in TMF through the Holocene, which contrasts with the gradual decrease of SST in the southwest Iberian margin. Overall, however, such features relate to higher frequency climate dynamics linked to the expression of prevailing atmospheric circulation patterns at different times during the Holocene (Rimbu et al., 2004; Jansen et al., 2009) and do not detract from the significance of long-term trends.

586

\section{Conclusions}

A new direct land-sea correlation study for the southwest Iberian margin reveals longterm vegetation/climatic patterns throughout the Holocene. The pollen analysis of core

591 D13882 allows the identification of the development and subsequent decline of the 
592 temperate and Mediterranean forests and pinewoods through the Holocene and the 593 development of heathlands. The observed changes are attributed to the effect of orbital 594 parameters, specifically summer insolation $\left(65^{\circ} \mathrm{N}\right)$ and precession. Our analysis sheds light 595 on the timing of maximum Holocene forest development in southwest IP between 9760 and $5967360 \mathrm{cal}$ yr BP, which lagged the maximum in SST (1000 yr) and the orbital insolation 597 maximum (2000 yr). We conclude that during the Early Holocene the northwest and 598 southwest regions were quite densely forested, at least in the more Atlantic fringes, triggered 599 by warm temperatures, high moisture availability and proximity to glacial refugia. The 600 delayed maximum in the southeast sector was most likely driven by lower moisture balance 601 with the most favourable conditions, eventually leading to the forest peak between 9000 and $6027500 \mathrm{cal}$ yr BP. A Middle Holocene heathland expansion suggests a more oceanic/Atlantic 603 prevailing climate. The major heathland development recorded in D13882, in particular, 604 represents a strongly distinctive feature of the regional biogeography of the southwest IP 605 which contrasts with the persistence of Mediterranean taxa and expansion of steppe 606 elements in the southeast IP.

607 Our analysis leads to three main conclusions: (1) stability of the Atlantic-to-Mediterranean Iberian moisture gradient across the Holocene, similar to present-day, reflected in the relative amplitude and composition of Holocene forests; (2) a time-transgressive pattern of maximum forest development along this moisture gradient from northwest (earliest) to southeast (latest), reflecting more critical limitations of moisture balance in the southeast IP

612 during the first millennium of the Holocene; (3) the fundamental mechanism for long-term

613 Holocene climate changes over the IP is orbital forcing (precession), expressed by the 614 development of forests near the summer insolation maximum (precession minimum) and 615 heathland expansion following the decrease of summer insolation towards the precession 616 maximum. This long term perspective emphasising the role of orbitally-driven climate 617 changes over the Holocene provides an essential baseline against which locally specific 618 changes related to rapid climate variability and human activity can be assessed.

\section{Acknowledgements}

622 The contributions of the following individuals are gratefully acknowledged: M.-H. Castéra; L. 623 Devaux; (Bordeaux 1 University, EPOC, UMR-CNRS 5805) for their assistance in 624 palynological treatments. This research was supported by the Portuguese Foundation for 625 Science and Technology (FCT) through the CLIMHOL (PTDC/AAC- CLI/100157/2008) and 626 ULTImATum (IF/01489/2015), CCMAR UID/multi/04326/2016, and SAICT-45-2017-02 627 projects (WARMWORLDS: 29897 and HOLMODRIVE: 29029), F. Naughton's CCMAR BCC 
grant (Incentivo/MAR/LA00015/2014) and IF grant (IF/01489/2015), S. Gomes PhD Grant (SFRH/BD/128984/2017) and T. Rodrigues grant (SFRH/BPD/108600/2015).

\section{References}

Abrantes, F., Lopes, C., Rodrigues, T., Gil, I., Witt, L., Grimalt, J. and Harris, I., 2009. Proxy calibration to instrumental data set: implications for paleoceanographic reconstructions. Geochemistry, Geophysics, Geosystems, 10 . doi: https://doi.org/10.1029/2009GC002604

Allen, J.R.M., Huntley, B. and Watts, W.A. 1996. The vegetation and climate of northwest Iberia over the last 14,000 years. Journal of Quaternary Science 11, pp.125-147. doi: https://doi.org/10.1002/(SICl)1099-1417(199603/04)11:2<125::AIDJQS232>3.0.CO;2-U

Amigo, J., Rodríguez-Guitián, M.A., Pradinho Honrado, J.J. and Alves, P., 2017. The Lowlands and Midlands of Northwestern Atlantic Iberia. In The vegetation of the Iberian Peninsula, (pp.191-250). Springer, Cham. doi: https://doi.org/10.1007/978-3319-54784-8_6

Andrés, C. and Ojeda, F., 2002. Effects of afforestation with pines on woody plant diversity of Mediterranean heathlands in southern Spain. Biodiversity \& Conservation, 11, pp.1511-1520.

Asensi, A. and Diez-Garretas, B., 2017. Coastal Vegetation. In The Vegetation of the Iberian Peninsula (pp. 397-432). Springer, Cham. Springer, Cham. doi: https://doi.org/10.1007/978-3-319-54784-8_6

Barbero, M., Loisel, R., Quezel, P., Richardson, D.M. and Romane, F., 1998. Pines of the Mediterranean Basin. Ecology and Biogeography of Pinus., pp.153-170.

Bartlein, P.J., Harrison, S.P., Brewer, S., Connor, S., Davis, B.A.S., Gajewski, K., Guiot, J., Harrison-Prentice, T.I., Henderson, A., Peyron, O. and Prentice, I.C., 2011. Pollenbased continental climate reconstructions at 6 and $21 \mathrm{ka}$ : a global synthesis. Climate Dynamics, 37, pp.775-802. doi: https://doi.org/10.1007/s00382-010-0904-1

Benito, G., Sopeña, A., Sánchez-Moya, Y., Machado, M.J. and Pérez-González, A., 2003. Palaeoflood record of the Tagus River (central Spain) during the Late Pleistocene and Holocene. Quaternary Science Reviews, 22, pp.1737-1756. doi: https://doi.org/10.1016/S0277-3791(03)00133-1

Bennett, K.D., 1994. Confidence intervals for age estimates and deposition times in lateQuaternary sediment sequences. The Holocene, 4, pp.337-348. doi: https://doi.org/10.1177/095968369400400401

Bennett, K.D., 2009. Documentation for psimpoll 4.27 and pscomb 1.03: C programs for plotting and analyzing pollen data. The 14Chrono Centre, Archaeology and 
Palaeoecology, Queen's University of Belfast, Belfast. [Online] Available at: http://www.chrono.qub.ac.uk/psimpoll/psimpoll.html. [Accessed 14 Jan. 2020]

Berger, A., 1978. Long-term variations of caloric insolation resulting from the earth's orbital elements. Quaternary Research, 9, 139-167.

Bernárdez, P., González-Álvarez, R., Francés, G., Prego, R., Bárcena, M.A. and Romero, O.E., 2008. Late Holocene history of the rainfall in the NW Iberian peninsulaevidence from a marine record. Journal of Marine Systems, 72, pp.366-382. doi: https://doi.org/10.1016/j.jmarsys.2007.03.009

Bosmans, J.H.C., Drijfhout, S.S., Tuenter, E., Hilgen, F.J., Lourens, L.J. and Rohling, E.J., 2015. Precession and obliquity forcing of the freshwater budget over the Mediterranean. Quaternary Science Reviews, 123, pp.16-30. doi: https://doi.org/10.1016/j.quascirev.2015.06.008

Brayshaw, D.J., Rambeau, C.M. and Smith, S.J., 2011. Changes in Mediterranean climate during the Holocene: Insights from global and regional climate modelling. The Holocene, 21, pp.15-31. doi: https://doi.org/10.1177/0959683610377528

Brewer, S., Guiot, J. and Torre, F., 2007. Mid-Holocene climate change in Europe: a datamodel comparison. Climate of the Past, 3, pp.499-512. doi: https://doi.org/10.5194/cp-3-499-2007

Cacho, I., Grimalt, J.O., Pelejero, C., Canals, M., Sierro, F.J., Flores, J.A. and Shackleton, N., 1999. Dansgaard-Oeschger and Heinrich event imprints in Alboran Sea paleotemperatures. Paleoceanography, 14, pp.698-705. doi: https://doi.org/10.1029/1999PA900044

Carré, M. and Cheddadi, R., 2017. Seasonality in long-term climate change. Quaternaire. Revue de l'Association française pour l'étude du Quaternaire, 28, pp.173-177.

Carrión, J.S. and van Geel, B., 1999. Fine-resolution Upper Weichselian and Holocene palynological record from Navarrés (Valencia, Spain) and a discussion about factors of Mediterranean forest succession. Review of Palaeobotany and Palynology, 106, pp.209-236. doi: https://doi.org/10.1016/S0034-6667(99)00009-3

Carrión, J.S., 2002. Patterns and processes of Late Quaternary environmental change in a montane region of southwestern Europe. Quaternary Science Reviews, 21, pp.20472066. doi: https://doi.org/10.1016/S0277-3791(02)00010-0

Carrión, J.S., Fuentes, N., González-Sampériz, P., Quirante, L.S., Finlayson, J.C., Fernández, S. and Andrade, A., 2007. Holocene environmental change in a montane region of southern Europe with a long history of human settlement. Quaternary Science Reviews, 26 , pp.1455-1475. doi: https://doi.org/10.1016/j.quascirev.2007.03.013 
Carrión, J.S., Fernández, S., González-Sampériz, P., Gil-Romera, G., Badal, E., CarriónMarco, Y., López-Merino, L., López-Sáez, J.A., Fierro, E. and Burjachs, F., 2010. Expected trends and surprises in the Lateglacial and Holocene vegetation history of the Iberian Peninsula and Balearic Islands. Review of Palaeobotany and Palynology, 162, pp.458-475. doi: https://doi.org/10.1016/j.revpalbo.2009.12.007

Carrión, J.S., Parra, I., Navarro, C. and Munuera, M., 2000. Past distribution and ecology of the cork oak (Quercus suber) in the Iberian Peninsula: a pollen-analytical approach. Diversity and Distributions, 6, pp.29-44. doi: https://doi.org/10.1046/j.14724642.2000.00070.x

Castéra, M-H. n.d. Pollen sample preparation. Pollen extraction protocol.PDF. [Online] Available at: http://www.ephepaleoclimat.com/Files/Other/Pollen\%20extraction\%20protocol.pdf. [Accessed 10 Jan. 2020]

Chabaud, L., Sánchez Goñi, M.F., Desprat, S. and Rossignol, L., 2014. Land-sea climatic variability in the eastern North Atlantic subtropical region over the last 14,200 years: Atmospheric and oceanic processes at different timescales. The Holocene, 24, pp.787-797. doi: https://doi.org/10.1177/0959683614530439

Cheddadi, R., Mamakowa, K., Guiot, J., de Beaulieu, J.L., Reille, M., Andrieu, V., Granoszewski, W. and Peyron, O., 1998. Was the climate of the Eemian stable? A quantitative climate reconstruction from seven European pollen records. Palaeogeography, Palaeoclimatology, Palaeoecology, 143, pp.73-85. doi: https://doi.org/10.1016/S0031-0182(98)00067-4

Cheddadi, R., Yu, G., Guiot, J., Harrison, S.P. and Prentice, I.C., 1996. The climate of Europe 6000 years ago. Climate Dynamics, 13, pp.1-9. doi: https://doi.org/10.1007/s003820050148

Combourieu Nebout, N., Peyron, O., Dormoy, I., Desprat, S., Beaudouin, C., Kotthoff, U. and Marret, F., 2009. Rapid climatic variability in the west Mediterranean during the last 25000 years from high resolution pollen data. Climate of the Past, 5, pp.503-521. doi: https://doi.org/10.5194/cp-5-503-2009

Connor, S.E., Araújo, J., van der Knaap, W.O. and van Leeuwen, J.F., 2012. A long-term perspective on biomass burning in the Serra da Estrela, Portugal. Quaternary Science Reviews, 55, pp.114-124. https://doi.org/10.1016/j.quascirev.2012.08.007

Consortium, P. 2k, Ahmed, M., Anchukaitis, K.J., Asrat, A., Borgaonkar, H.P., Braida, M., Buckley, B.M., Büntgen, U., Chase, B.M., Christie, D.A., Cook, E.R. and Curran, M.A., 2013. Continental-scale temperature variability during the past two millennia. Nature Geoscience, 6, pp.339-346. doi: https://doi.org/10.1038/ngeo1797

Costa, J.C., Neto, C., Aguiar, C., Capelo, J., Espírito Santo, M.D., Honrado, J., and Lousã, 
M. (2012). Vascular plant communities in Portugal (Continental, the Azores and Madeira). Global Geobotany, 2, pp.1-180. doi: 10.5616/gg 120001

Daveau, S., 1980. Espaço e tempo: evolução do ambiente geográfico de Portugal ao longo dos tempos pré-históricos. Clio. Revista do Centro de História da Universidade de Lisboa, 2, pp.13-37.

Davis, B.A. and Brewer, S., 2009. Orbital forcing and role of the latitudinal insolation/temperature gradient. Climate Dynamics, 32, pp.143-165. doi: https://doi.org/10.1007/s00382-008-0480-9

Davis, B.A., Brewer, S., Stevenson, A.C. and Guiot, J., 2003. The temperature of Europe during the Holocene reconstructed from pollen data. Quaternary Science Reviews, 22, pp.1701-1716. doi: https://doi.org/10.1016/S0277-3791(03)00173-2

de Benito, N.,1948. Brezales y brezos. Instituto Forestal de Contrib. Bolus Herb. 13, pp.158208. Investigaciones y Experiencias, Madrid. http://bibdigital.rjb.csic.es/ing/Libro.php?Libro=776

deMenocal, P.B., 2001. Cultural responses to climate change during the Late Holocene. Science, 292, pp.667-673. https://doi.org/10.1126/SCIENCE.1059287

deMenocal, P.B. and Tierney, J.E., 2012. Green Sahara: African humid periods paced by earth's orbital changes. Nature Education Knowledge, 3, p.12.

Désamoré, A., Laenen, B., Devos, N., Popp, M., González-Mancebo, J.M., Carine, M.A. and Vanderpoorten, A., 2011. Out of Africa: north-westwards Pleistocene expansions of the heather Erica arborea. Journal of Biogeography, 38, pp.164-176. doi: https://doi.org/10.1111/j.1365-2699.2010.02387.x

Desprat, S., Combourieu-Nebout, N., Essallami, L., Sicre, M.A., Dormoy, I., Peyron, O., Siani, G., Roumazeilles, V.B. and Turon, J.L., 2013. Deglacial and Holocene vegetation and climatic changes in the southern Central Mediterranean from a direct land-sea correlation. Climate of the Past, 9, pp.767-787. doi: https://doi.org/10.5194/cp-9-767-2013

Desprat, S., Díaz Fernández, P.M., Coulon, T., Ezzat, L., Pessarossi-Langlois, J., Gil, L., Morales-Molino, C. and Sánchez Goñi, M.F., 2015. Pinus nigra (European black pine) as the dominant species of the last glacial pinewoods in south-western to central Iberia: a morphological study of modern and fossil pollen. Journal of Biogeography, 42, pp.1998-2009. doi: https://doi.org/10.1111/jbi.12566

Desprat, S., Sánchez Goñi, M.F., McManus, J.F., Duprat, J. and Cortijo, E., 2009. Millennialscale climatic variability between 340000 and 270000 years ago in SW Europe: evidence from a NW Iberian margin pollen sequence. Climate of the Past, 5, pp.5372. doi: https://doi.org/10.5194/cp-5-53-2009

Desprat, S., Sánchez Goñi, M.F., Naughton, F., Turon, J.L., Duprat, J., Malaizé, B., Cortijo, 
E. and Peypouquet, J.P., 2007. 25. Climate variability of the last five isotopic interglacials: Direct land-sea-ice correlation from the multiproxy analysis of NorthWestern Iberian margin deep-sea cores. In Developments in Quaternary Sciences, 7, pp.375-386. Elsevier. doi: https://doi.org/10.1016/S1571-0866(07)80050-9

Desprat, S., Sánchez Goñi, M.F., Turon, J.L., McManus, J.F., Loutre, M.F., Duprat, J., Malaize, B., Peyron, O. and Peypouquet, J.P., 2005. Is vegetation responsible for glacial inception during periods of muted insolation changes?. Quaternary Science Reviews, 24, pp.1361-1374. doi: https://doi.org/10.1016/j.quascirev.2005.01.005

Dessandier, P.A., Bonnin, J., Malaizé, B., Lambert, C., Tjallingii, R., Warden, L., Damsté, J.S.S. and Kim, J.H., 2018. Variations in benthic foraminiferal assemblages in the Tagus mud belt during the last 5700 years: Implications for Tagus River discharge. Palaeogeography, Palaeoclimatology, Palaeoecology, 496, pp.225-237. doi: https://doi.org/10.1016/j.palaeo.2018.01.040

Di Rita, F., Fletcher, W.J., Aranbarri, J., Margaritelli, G., Lirer, F. and Magri, D., 2018. Holocene forest dynamics in central and western Mediterranean: periodicity, spatiotemporal patterns and climate influence. Scientific reports, 8, p.8929. doi: https://doi.org/10.1038/s41598-018-27056-2

Dormoy, I., Peyron, O., Combourieu Nebout, N., Goring, S., Kotthoff, U., Magny, M. and Pross, J., 2009. Terrestrial climate variability and seasonality changes in the Mediterranean region between 15000 and 4000 years BP deduced from marine pollen records. Climate of the Past, 5, pp.615-632. doi: https://doi.org/10.5194/cp-5615-2009

Drysdale, R., Zanchetta, G., Hellstrom, J., Maas, R., Fallick, A., Pickett, M., Cartwright, I. and Piccini, L., 2006. Late Holocene drought responsible for the collapse of Old World civilizations is recorded in an Italian cave flowstone. Geology, 34, pp.101-104. doi: https://doi.org/10.1130/G22103.1

Espírito-Santo, D., Capelo, J., Neto, C., Pinto-Gomes, C., Ribeiro, S., Canas, R.Q., and Costa, J.C. (2017). Lusitania. In The Vegetation of the Iberian Peninsula, pp. 35-82. Springer, Cham. doi: https://doi.org/10.1007/978-3-319-54867-8_2

European Forest Genetic Resources Programme, genetic diversity is the base of the resilence (EUROFORGEN). 2009. Species. [online] Available at: http://www.euforgen.org/species/. [Accessed 4 Oct. 2019].

Faegri, K., Kaland, P.E. and Krzywinski, K., 1989. Textbook of pollen analysis. No. Ed. 4. John Wiley \& Sons Ltd.

Fick, S.E. and Hijmans, R.J., 2017. WorldClim 2: new 1-km spatial resolution climate surfaces for global land areas. International journal of climatology, 37, pp.4302-4315. doi: https://doi.org/10.1002/joc.5086 
Figueiral, I. and Carcaillet, C., 2005. A review of Late Pleistocene and Holocene biogeography of highland Mediterranean pines (Pinus type sylvestris) in Portugal, based on wood charcoal. Quaternary Science Reviews, 24, pp.2466-2476. doi: https://doi.org/10.1016/j.quascirev.2005.02.004

Figueiral, I. and Terral, J.F., 2002. Late Quaternary refugia of Mediterranean taxa in the Portuguese Estremadura: charcoal based palaeovegetation and climatic reconstruction. Quaternary Science Reviews, 21, pp.549-558. doi: https://doi.org/10.1016/S0277-3791(01)00022-1

Fiuza, A.F.G., 1984. Hidrologia e dinamica das aguas costeiras de Portugal (Hydrology and dynamics of the Portuguese coastal water). University of Lisbon, Lisbon, Portugal (PhD thesis).

Fletcher, W.J., 2005. Holocene Landscape History of Southern Portugal. University of Cambridge, Cambridge, United Kingdom (PhD thesis).

Fletcher, W.J. and Sánchez Goñi, M.F., 2008. Orbital-and sub-orbital-scale climate impacts on vegetation of the western Mediterranean basin over the last 48,000 yr. Quaternary Research, 70, pp.451-464. doi: https://doi.org/10.1016/j.yqres.2008.07.002

Fletcher, W.J., Boski, T. and Moura, D., 2007. Palynological evidence for environmental and climatic change in the lower Guadiana valley, Portugal, during the last 13000 years. The Holocene, 17, pp.481-494. doi: https://doi.org/10.1177/0959683607077027

Fletcher, W.J., Debret, M. and Sánchez Goñi, M.F., 2013. Mid-Holocene emergence of a low-frequency millennial oscillation in western Mediterranean climate: Implications for past dynamics of the North Atlantic atmospheric westerlies. The Holocene, 23, pp.153-166. doi: https://doi.org/10.1177/0959683612460783

Fletcher, W.J., Sánchez Goñi, M.F., Peyron, O. and Dormoy, I., 2010. Abrupt climate changes of the last deglaciation detected in a Western Mediterranean forest record. Climate of the Past, 6, pp.245-264. doi: https://doi.org/10.5194/cp-6-245-2010

Fyfe, R.M., Woodbridge, J. and Roberts, N., 2015. From forest to farmland: pollen-inferred land cover change across Europe using the pseudobiomization approach. Global Change Biology, 21, pp.1197-1212. doi: https://doi.org/10.1111/gcb.12776

García-Amorena, I., Manzaneque, F.G., Rubiales, J.M., Granja, H.M., de Carvalho, G.S. and Morla, C., 2007. The Late Quaternary coastal forests of western Iberia: a study of their macroremains. Palaeogeography, Palaeoclimatology, Palaeoecology, 254, pp.448-461. doi: https://doi.org/10.1016/j.palaeo.2007.07.003

Garreta, V., Guiot, J., Mortier, F., Chadœuf, J. and Hély, C., 2012. Pollen-based climate reconstruction: Calibration of the vegetation-pollen processes. Ecological modelling, 235, pp.81-94. doi: https://doi.org/10.1016/j.ecolmodel.2012.03.031 
Gimeno, L., Nieto, R., Trigo, R.M., Vicente-Serrano, S.M. and López-Moreno, J.I., 2010. Where does the Iberian Peninsula moisture come from? An answer based on a Lagrangian approach. Journal of Hydrometeorology, 11, pp.421-436.

Gómez-Orellana, L.R., Ramil-Rego, P. and Sánchez, S.M., 2001. Modificaciones del paisaje durante el Pleistoceno Superior-Holoceno en los territorios litorales atlánticos del NW Ibérico. Estudos do Quaternário/Quaternary Studies| Online ISSN: 2182-8660| Print ISSN: 0874-0801, 4, pp.79-96.

Heusser, L. and Balsam, W.L., 1977. Pollen distribution in the northeast Pacific Ocean. Quaternary Research, 7, pp.45-62. doi: https://doi.org/10.1016/0033-5894(77)900138

Heusser, L.E. and Stock, C.E., 1984. Preparation techniques for concentrating pollen from marine sediments and other sediments with low pollen density. Palynology, 8, pp.225-227. doi: https://doi.org/10.1080/01916122.1984.9989279

Jalut, G., Amat, A.E., Bonnet, L., Gauquelin, T. and Fontugne, M., 2000. Holocene climatic changes in the Western Mediterranean, from south-east France to south-east Spain. Palaeogeography, Palaeoclimatology, Palaeoecology, 160, pp.255-290. doi: https://doi.org/10.1016/S0031-0182(00)00075-4

Jansen, E., Andersson, C., Moros, M., Nisancioglu, K.H., Nyland, B.F. and Telford, R.J., 2008. The Early to Mid-Holocene thermal optimum in the North Atlantic Natural Climate Variability and Global Warming-A Holocene Perspective, edited by: Battarbee, RW and Binney, HA, Wiley-Blackwell, Chichester, pp.123-137. doi: https://doi.org/10.1002/9781444300932.ch5

Jerez, S., Trigo, R.M., Vicente-Serrano, S.M., Pozo-Vázquez, D., Lorente-Plazas, R., Lorenzo-Lacruz, J., Santos-Alamillos, F. and Montávez, J.P., 2013. The impact of the North Atlantic Oscillation on renewable energy resources in southwestern Europe. Journal of Applied Meteorology and Climatology, 52, pp.2204-2225. doi: https://doi.org/10.1175/JAMC-D-12-0257.1

Kageyama, M., Nebout, N.C., Sepulchre, P., Peyron, O., Krinner, G., Ramstein, G. and Cazet, J.P., 2005. The Last Glacial Maximum and Heinrich Event 1 in terms of climate and vegetation around the Alboran Sea: a preliminary model-data comparison. Comptes Rendus Geoscience, 337, pp.983-992. doi: https://doi.org/10.1016/j.crte.2005.04.012

Kuper, R. and Kröpelin, S., 2006. Climate-controlled Holocene occupation in the Sahara: motor of Africa's evolution. Science, 313, pp.803-807. doi: https://doi.org/10.1126/SCIENCE.1130989

López de Heredia, U., Carrión, J.S., Jiménez, P., Collada, C. and Gil, L., 2007. Molecular and palaeoecological evidence for multiple glacial refugia for evergreen oaks on the 
Iberian Peninsula. Journal of Biogeography, 34, pp.1505-1517. doi: https://doi.org/10.1111/j.1365-2699.2007.01715.x

Lionello, P., Malanotte-Rizzoli, P., Boscolo, R., Alpert, P., Artale, V., Li, L., Luterbacher, J., May, W., Trigo, R., Tsimplis, M. and Ulbrich, U., 2006. The Mediterranean climate: an overview of the main characteristics and issues.

Liu, Z., Zhu, J., Rosenthal, Y., Zhang, X., Otto-Bliesner, B.L., Timmermann, A., Smith, R.S., Lohmann, G., Zheng, W. and Timm, O.E., 2014. The Holocene temperature conundrum. Proceedings of the National Academy of Sciences, 111, pp.E3501E3505. doi: https://doi.org/10.1073/pnas.1407229111

Macdonald, A.M. and Wunsch, C., 1996. An estimate of global ocean circulation and heat fluxes. Nature, 382, p.436.

López-Merino, L., Sánchez, N.S., Kaal, J., López-Sáez, J.A. and Cortizas, A.M., 2012. Postdisturbance vegetation dynamics during the Late Pleistocene and the Holocene: an example from NW Iberia. Global and Planetary Change, 92, pp.58-70. doi: https://doi.org/10.1016/j.gloplacha.2012.04.003

Magri, D. and Tzedakis, P.C., 2000. Orbital signatures and long-term vegetation patterns in the Mediterranean. Quaternary International, 73, pp.69-78. doi: https://doi.org/10.1016/S1040-6182(00)00065-3

Maksic, J., Shimizu, M.H., de Oliveira, G.S., Venancio, I.M., Cardoso, M. and Ferreira, F.A., 2019. Simulation of the Holocene climate over South America and impacts on the vegetation. Holocene, 29, pp.287-299. doi: https://doi.org/10.1177/0959683618810406

Marchal, O., Cacho, I., Stocker, T.F., Grimalt, J.O., Calvo, E., Martrat, B., Shackleton, N., Vautravers, M., Cortijo, E., van Kreveld, S. and Andersson, C., 2002. Apparent longterm cooling of the sea surface in the northeast Atlantic and Mediterranean during the Holocene. Quaternary Science Reviews, 21, pp.455-483. doi: https://doi.org/10.1016/S0277-3791(01)00105-6

Marcott, S.A., Shakun, J.D., Clark, P.U. and Mix, A.C., 2013. A reconstruction of regional and global temperature for the past 11,300 years. Science, 339, pp.1198-1201. doi: https://doi.org/10.1126/science.1228026

Margari, V., Skinner, L.C., Hodell, D.A., Martrat, B., Toucanne, S., Grimalt, J.O., Gibbard, P.L., Lunkka, J.P. and Tzedakis, P.C., 2014. Land-ocean changes on orbital and millennial time scales and the penultimate glaciation. Geology, 42, pp.183-186. doi: https://doi.org/10.1130/G35070.1

Margari, V., Skinner, L.C., Tzedakis, P.C., Ganopolski, A., Vautravers, M. and Shackleton, N.J., 2010. The nature of millennial-scale climate variability during the past two glacial periods. Nature Geoscience, 3, p.127. doi: https://doi.org/10.1038/ngeo740 
Margari, V., Tzedakis, P.C., Shackleton, N.J. and Vautravers, M., 2007. Vegetation response in SW Iberia to abrupt climate change during MIS 6: direct land-sea comparisons. Quaternary International, 167, pp.267-268.

Marsicek, J., Shuman, B.N., Bartlein, P.J., Shafer, S.L. and Brewer, S., 2018. Reconciling divergent trends and millennial variations in Holocene temperatures. Nature, 554, pp.92-96. doi: https://doi.org/10.1038/nature25464

Mateus, J., 1992. Holocene and present-day ecosystems of the Carvalhal Region. Southwest Portugal. University of Utrecht, Utrecht, Netherlands (PhD thesis).

Mateus, J.E., 1989. Lagoa Travessa: a Holocene pollen diagram from the south-west coast of Portugal. Revista de Biologia, 14, pp.17-94.

Mauri, A., Davis, B.A.S., Collins, P.M. and Kaplan, J.O., 2015. The climate of Europe during the Holocene: a gridded pollen-based reconstruction and its multi-proxy evaluation. Quaternary Science Reviews, 112, pp.109-127. doi: https://doi.org/10.1016/J.QUASCIREV.2015.01.013

McAndrews, J.H. and King, J.E., 1976. Pollen of the North American Quaternary: the top twenty. Geoscience and Man, 15, pp.41-49. doi: 10.2307/3687256

Montero-Serrano, J.C., Bout-Roumazeilles, V., Sionneau, T., Tribovillard, N., Bory, A., Flower, B.P., Riboulleau, A., Martinez, P. and Billy, I., 2010. Changes in precipitation regimes over North America during the Holocene as recorded by mineralogy and geochemistry of Gulf of Mexico sediments. Global and Planetary Change, 74, pp.132-143. doi: 10.1016/j.gloplacha.2010.09.004.

Moore, P.D., Webb, J.A. and Collison, M.E., 1991. Pollen analysis. Blackwell scientific publications.

Morales-Molino, C. and García-Antón, M., 2014. Vegetation and fire history since the last glacial maximum in an inland area of the western Mediterranean Basin (Northern Iberian Plateau, NW Spain). Quaternary Research, 81, pp.63-77. doi: https://doi.org/10.1016/j.yqres.2013.10.010

Morales-Molino, C., García-Antón, M., Postigo-Mijarra, J.M. and Morla, C., 2013. Holocene vegetation, fire and climate interactions on the westernmost fringe of the Mediterranean Basin. Quaternary Science Reviews, 59, pp.5-17. doi: https://doi.org/10.1016/j.quascirev.2012.10.027

Morellón, M., Aranbarri, J., Moreno, A., González-Sampériz, P. and Valero-Garcés, B.L., 2018. Early Holocene humidity patterns in the Iberian Peninsula reconstructed from lake, pollen and speleothem records. Quaternary Science Reviews, 181, pp.1-18. doi: https://doi.org/10.1016/j.quascirev.2017.11.016

Müller, P.J., Kirst, G., Ruhland, G., Von Storch, I. and Rosell-Melé, A., 1998. Calibration of the alkenone paleotemperature index $U^{37} K^{\prime}$ based on core-tops from the eastern 
South Atlantic and the global ocean $\left(60^{\circ} \mathrm{N}-60^{\circ} \mathrm{S}\right)$. Geochimica et Cosmochimica Acta, 62, pp.1757-1772. doi: https://doi.org/10.1016/S0016-7037(98)00097-0

Naughton, F., Costas, S., Gomes, S.D., Desprat, S., Rodrigues, T., Sánchez Goñi, M.F., Renssen, H., Trigo, R., Bronk-Ramsey, C., Oliveira, D. and Salgueiro, E., 2019. Coupled ocean and atmospheric changes during Greenland stadial 1 in southwestern Europe. Quaternary Science Reviews, 212, pp.108-120. doi: https://doi.org/10.1016/j.quascirev.2019.03.033

Naughton, F., Sánchez Goñi, M.S., Desprat, S., Turon, J.L., Duprat, J., Malaizé, B., Joli, C., Cortijo, E., Drago, T. and Freitas, M.C., 2007. Present-day and past (last 25000 years) marine pollen signal off western Iberia. Marine Micropaleontology, 62, pp.91114. doi: https://doi.org/10.1016/j.marmicro.2006.07.006

Naughton, F., Sánchez Goñi, M.S., Kageyama, M., Bard, E., Duprat, J., Cortijo, E., Desprat, S., Malaizé, B., Joly, C., Rostek, F. and Turon, J.L., 2009. Wet to dry climatic trend in north-western Iberia within Heinrich events. Earth and Planetary Science Letters, 284, pp.329-342. doi: https://doi.org/10.1016/j.epsl.2009.05.001

Naughton, F., Sánchez Goñi, M.S., Rodrigues, T., Salgueiro, E., Costas, S., Desprat, S., Duprat, J., Michel, E., Rossignol, L., Zaragosi, S. and Voelker, A.H.L., 2016. Climate variability across the last deglaciation in NW Iberia and its margin. Quaternary International, 414, pp.9-22. doi: https://doi.org/10.1016/j.quaint.2015.08.073

Neto, C., Arsénio, P. and Costa, J.C., 2009. Flora e Vegetação do sudoeste de Portugal continental. Quercetea, 9, pp.43-144.

Niedermeyer, E.M., Schefuß, E., Sessions, A.L., Mulitza, S., Mollenhauer, G., Schulz, M. and Wefer, G., 2010. Orbital-and millennial-scale changes in the hydrologic cycle and vegetation in the western African Sahel: insights from individual plant wax $\delta D$ and $\delta^{13} \mathrm{C}$. Quaternary Science Reviews, 29, pp.2996-3005. doi: https://doi.org/10.1016/j.quascirev.2010.06.039

O'Sullivan, P., 2008. The 'collapse' of civilizations: what palaeoenvironmental reconstruction cannot tell us, but anthropology can. The Holocene, 18, pp.45-55. doi: https://doi.org/10.1177/0959683607085595

Ojeda, F., Arroyo, J. and Marañón, T., 1998. The phytogeography of European and Mediterranean heath species (Ericoideae, Ericaceae): a quantitative analysis. Journal of Biogeography, 25, pp.165-178.

Oliveira, D., Desprat, S., Rodrigues, T., Naughton, F., Hodell, D., Trigo, R., Rufino, M., Lopes, C., Abrantes, F. and Sánchez Goñi, M.F., 2016. The complexity of millennialscale variability in southwestern Europe during MIS 11. Quaternary Research, 86, pp.373-387. doi: https://doi.org/10.1016/j.yqres.2016.09.002 
Oliveira, D., Goñi, M.F.S., Naughton, F., Polanco-Martínez, J.M., Jimenez-Espejo, F.J., Grimalt, J.O., Martrat, B., Voelker, A.H., Trigo, R., Hodell, D. and Abrantes, F., 2017. Unexpected weak seasonal climate in the western Mediterranean region during MIS 31, a high-insolation forced interglacial. Quaternary Science Reviews, 161, pp.1-17. doi: https://doi.org/10.1016/j.quascirev.2017.02.013

Oliveira, D., Desprat, S., Yin, Q., Naughton, F., Trigo, R., Rodrigues, T., Abrantes, F. and Sánchez Goñi, M.F., 2018. Unraveling the forcings controlling the vegetation and climate of the best orbital analogues for the present interglacial in SW Europe. Climate Dynamics, 51, pp.667-686. doi: https://doi.org/10.1007/s00382-017-3948-7

Peliz, Á., Dubert, J., Santos, A.M.P., Oliveira, P.B. and Le Cann, B., 2005. Winter upper ocean circulation in the Western Iberian Basin-Fronts, Eddies and Poleward Flows: an overview. Deep sea research Part l: Oceanographic research papers, 52, pp.621646. doi: https://doi.org/10.1016/j.dsr.2004.11.005

Penalba, M.C., 1994. The history of the Holocene vegetation in northern Spain from pollen analysis. Journal of Ecology, pp.815-832. doi: 10.2307/2261446

Peyron, O., Combourieu-Nebout, N., Brayshaw, D., Goring, S., Andrieu-Ponel, V., Desprat, S., Fletcher, W., Gambin, B., Ioakim, C., Joannin, S. and Kotthoff, U., 2017. Precipitation changes in the Mediterranean basin during the Holocene from terrestrial and marine pollen records: a model-data comparison. Climate of the Past, 13, pp.249-265. doi: https://doi.org/10.5194/cp-13-249-2017

Polunin, O. and Walters, M., 1985. Guide to the Vegetation of Britain and Europe. Oxford University Press.

Praetorius, S.K., McManus, J.F., Oppo, D.W. and Curry, W.B., 2008. Episodic reductions in bottom-water currents since the last ice age. Nature Geoscience, 1, p.449. doi: 10.1038/ngeo227

Prahl, F.G. and Wakeman, S.G., 1987. Calibration of unsaturation patterns in long-chain alkenones as indicators of paleoceanographic conditions. Nature, 330, pp.367-369.

Queiroz, P., 1999. Ecologia Historica da Paisagem do Noroeste Alentejano.University of Lisbon, Lisbon, Portugal (Ph.D. thesis).

Queiroz, P.F. and Mateus, J.E., 2004. Paleoecologia litoral entre Lisboa e Sines: do Tardiglaciário aos tempos de hoje. Evolução Geohistórica do Litoral Português e Fenómenos Correlatives, edited by AA Tavares, MJF Tavares, and JL Cardoso. Universidade Aberta, Lisbon, Portugal.

Queiroz, P.F., 1989. A preliminary paleoecological study at Estacada (Lagoa de Albufeira). Revista de Biologia, 14, pp.3-16.

Quezel, P., 2000. Reflections on the evolution of the flora and vegetation in Mediterranean Maghreb. Paris: Ibis Press, 117 p. 
Ramos-Román, M.J., Jiménez-Moreno, G., Camuera, J., García-Alix, A., Anderson, R.S., Jiménez-Espejo, F.J., Sachse, D., Toney, J.L., Carrión, J.S., Webster, C. and Yanes, Y., 2018. Millennial-scale cyclical environment and climate variability during the Holocene in the western Mediterranean region deduced from a new multi-proxy analysis from the Padul record (Sierra Nevada, Spain). Global and Planetary Change, 168, pp.35-53.

Reille, M., 1992. Pollen et spores d'Europe et d'Afrique du nord: Laboratoire de botanique historique et palynologie. URA CNRS, Marseille, France.

Reille, M., 1995. Pollen et spores d'Europe et d'Afrique du Nord (Vol. 2). Laboratoire de Botanique historique et Palynologie.

Renssen, H. and Isarin, R.F., 2001. The two major warming phases of the last deglaciation at 14.7 and $11.5 \mathrm{ka}$ cal BP in Europe: climate reconstructions and AGCM experiments. Global and Planetary Change, 30, pp.117-153. doi: https://doi.org/10.1016/S0921-8181(01)00082-0

Rivas-Martínez, S., Penas, Á., González, T.E.D., Cantó, P., del Río, S., Costa, J.C., Herrero, L. and Molero, J., 2017. Biogeographic units of the Iberian Peninsula and Baelaric Islands to district level. A concise synopsis. In The vegetation of the Iberian Peninsula (pp.131-188). Springer, Cham.

Rochon, A. and Vernal, A.D., 1994. Palynomorph distribution in recent sediments from the Labrador Sea. Canadian Journal of Earth Sciences, 31, pp.115-127. doi: https://doi.org/10.1139/e94-010

Rodrigo, F.S., Esteban-Parra, M.J., Pozo-Vázquez, D. and Castro-Díez, Y., 1999. A 500year precipitation record in Southern Spain. International Journal of Climatology: A Journal of the Royal Meteorological Society, 19, pp.1233-1253. doi: https://doi.org/10.1002/(SICI)1097-0088(199909)19:11<1233::AIDJOC413>3.0.CO;2-L

Rodrigues, T., Grimalt, J.O., Abrantes, F., Naughton, F. and Flores, J.A., 2010. The last glacial-interglacial transition (LGIT) in the western mid-latitudes of the North Atlantic: Abrupt sea surface temperature change and sea-level implications. Quaternary Science Reviews, 29, pp.1853-1862. doi: https://doi.org/10.1016/j.quascirev.2010.04.004

Rodrigues, T., Grimalt, J.O., Abrantes, F.G., Flores, J.A. and Lebreiro, S.M., 2009. Holocene interdependences of changes in sea surface temperature, productivity, and fluvial inputs in the Iberian continental shelf (Tagus mud patch). Geochemistry, Geophysics, Geosystems, 10. doi: https://doi.org/10.1029/2008GC002367

Rodríguez-Sánchez, F., Hampe, A., Jordano, P. and Arroyo, J., 2010. Past tree range dynamics in the Iberian Peninsula inferred through phylogeography and 
palaeodistribution modelling: a review. Review of Palaeobotany and Palynology, 162, pp.507-521. doi: https://doi.org/10.1016/j.revpalbo.2010.03.008

Roucoux, K.H., De Abreu, L., Shackleton, N.J. and Tzedakis, P.C., 2005. The response of NW Iberian vegetation to North Atlantic climate oscillations during the last $65 \mathrm{kyr}$. Quaternary Science Reviews, 24, pp.1637-1653. doi: https://doi.org/10.1016/J.QUASCIREV.2004.08.022

Roucoux, K.H., Shackleton, N.J., de Abreu, L., Schönfeld, J. and Tzedakis, P.C., 2001. Combined marine proxy and pollen analyses reveal rapid Iberian vegetation response to North Atlantic millennial-scale climate oscillations. Quaternary Research, 56, pp.128-132. doi: https://doi.org/10.1006

Roucoux, K.H., Tzedakis, P.C., De Abreu, L. and Shackleton, N.J., 2006. Climate and vegetation changes 180,000 to 345,000 years ago recorded in a deep-sea core off Portugal. Earth and Planetary Science Letters, 249, pp.307-325. doi: https://doi.org/10.1016/J.EPSL.2006.07.005

Salgueiro, E., Naughton, F., Voelker, A.H.L., de Abreu, L., Alberto, A., Rossignol, L., Duprat, J., Magalhães, V.H., Vaqueiro, S., Turon, J.L. and Abrantes, F., 2014. Past circulation along the western Iberian margin: a time slice vision from the Last Glacial to the Holocene. Quaternary Science Reviews, 106, pp.316-329. doi: https://doi.org/10.1016/j.quascirev.2014.09.001

Sánchez Goñi, M.F, Cacho, I., Turon, J.L., Guiot, J., Sierro, F.J., Peypouquet, J.P., Grimalt, J.O. and Shackleton, N.J., 2002. Synchroneity between marine and terrestrial responses to millennial-scale climatic variability during the last glacial period in the Mediterranean region. Climate Dynamics, 19, pp.95-105. doi: https://doi.org/10.1007/s00382-001-0212-x

Sánchez Goñi, M.F., Bakker, P., Desprat, S., Carlson, A.E., Van Meerbeeck, C.J., Peyron, O., Naughton, F., Fletcher, W.J., Eynaud, F., Rossignol, L. and Renssen, H., 2012. European climate optimum and enhanced Greenland melt during the Last Interglacial. Geology, 40, pp.627-630. doi: https://doi.org/10.1130/G32908.1

Sánchez Goñi, M.F., Desprat, S., Fletcher, W.J., Morales-Molino, C., Naughton, F., Oliveira, D., Urrego, D.H. and Zorzi, C., 2018. Pollen from the deep-sea: a breakthrough in the mystery of the Ice Ages. Frontiers in Plant Science, 9, p.38. doi: https://doi.org/10.3389/fpls.2018.00038

Sánchez Goñi, M.F., Desprat, S., Daniau, A.L., Bassinot, F.C., Polanco-Martínez, J.M., Harrison, S.P., Allen, J.R., Scott Anderson, R., Behling, H., Bonnefille, R. and Burjachs, F., 2017. The ACER pollen and charcoal database: a global resource to document vegetation and fire response to abrupt climate changes during the last glacial period. Earth System Science Data, 9, pp.679-695. doi: 
https://doi.org/10.5194/essd-9-679-2017

Sánchez Goñi, M.S., Turon, J.L., Eynaud, F., Shackleton, N.J. and Cayre, O., 2000. Direct land/sea correlation of the Eemian, and its comparison with the Holocene: a highresolution palynological record off the Iberian margin. Geologie en Mijnbouw, 79, pp.345-356.

Sánchez-López, G., Hernández, A., Pla-Rabès, S., Trigo, R.M., Toro, M., Granados, I., Sáez, A., Masqué, P., Pueyo, J.J., Rubio-Inglés, M.J. and Giralt, S., 2016. Climate reconstruction for the last two millennia in central Iberia: The role of East Atlantic (EA), North Atlantic Oscillation (NAO) and their interplay over the Iberian Peninsula. Quaternary Science Reviews, 149, pp.135-150. doi: https://doi.org/10.1016/j.quascirev.2016.07.021

Santos, L. and Sánchez Goñi, M.F. 2003. Lateglacial and Holocene environmental changes in Portuguese coastal lagoons 3: vegetation history of the Santo Andre coastal area. The Holocene, 13(3), pp.459-464. doi: https://doi.org/10.1191/0959683603hl638rp

Serrano, A., García, J., Mateos, V.L., Cancillo, M.L. and Garrido, J., 1999. Monthly modes of variation of precipitation over the Iberian Peninsula. Journal of Climate, 12, pp.28942919. doi: https://doi.org/10.1175/1520-0442(1999)012<2894:MMOVOP>2.0.CO;2

Shackleton, N.J., Fairbanks, R.G., Chiu, T.C. and Parrenin, F., 2004. Absolute calibration of the Greenland time scale: implications for Antarctic time scales and for $\Delta 14 \mathrm{C}$. Quaternary Science Reviews, 23, pp.1513-1522. doi: https://doi.org/10.1016/j.quascirev.2004.03.006

Shackleton, N.J., Hall, M.A. and Vincent, E., 2000. Phase relationships between millennialscale events 64,000-24,000 years ago. Paleoceanography, 15, pp.565-569. doi: https://doi.org/10.1029/2000PA000513

Shakun, J.D., 2018. Pollen weighs in on a climate conundrum. Nature, 554, pp.39-40. doi: https://doi.org/10.1038/d41586-018-00943-4

Stockmarr, J.A., 1971. Tablets with spores used in absolute pollen analysis. Pollen spores, 13, pp.615-621.

Tarroso, P., Carrión, J., Dorado-Valiño, M., Queiroz, P., Santos, L., Valdeolmillos-Rodríguez, A., Célio Alves, P., Brito, J.C. and Cheddadi, R., 2016. Spatial climate dynamics in the Iberian Peninsula since 15000 yr BP. Climate of the Past, 12, pp.1137-1149. doi: https://doi.org/10.5194/cp-12-1137-2016

Thatcher, D.L., Wanamaker, A.D., Denniston, R.F., Asmeron, Y., Polyak, V.J., Fullick, D., Ummenhofer, C.C., Gillikin, D.P., Haws, J.A. 2020. Hydroclimate variability from western Iberia (Portugal) during the Holocene: Insights from a composite stalagmite isotope record. The Holocene, pp. 1-16. doi: https://doi.org/10.1177/0959683620908648 
Trigo, R.M. and da Camara, C.C., 2000. Circulation weather types and their influence on the precipitation regime in Portugal. International Journal of Climatology: A Journal of the Royal Meteorological Society, 20, pp.1559-1581. doi: https://doi.org/10.1002/10970088(20001115)20:13<1559::AID-JOC555>3.0.CO;2-5

Trigo, R.M., Añel, J.A., Barriopedro, D., García-Herrera, R., Gimeno, L., Nieto, R., Castillo, R., Allen, M.R. and Massey, N., 2013. The record winter drought of 2011-12 in the Iberian Peninsula. Bulletin of the American Meteorological Society, 94, p.S41.

Trigo, R.M., Pozo-Vázquez, D., Osborn, T.J., Castro-Díez, Y., Gámiz-Fortis, S. and EstebanParra, M.J., 2004. North Atlantic Oscillation influence on precipitation, river flow and water resources in the Iberian Peninsula. International Journal of Climatology: A Journal of the Royal Meteorological Society, 24, pp.925-944. doi: https://doi.org/10.1002/joc.1048

Trigo, R.M., Valente, M.A., Trigo, I.F., Miranda, P.M., Ramos, A.M., Paredes, D. and GarcíaHerrera, R., 2008. The impact of North Atlantic wind and cyclone trends on European precipitation and significant wave height in the Atlantic. Annals of the New York Academy of Sciences, 1146, pp.212-234. doi: 10.1196/annals.1446.014

Turner, C. and Hannon, G.E., 1988. Vegetational evidence for late Quaternary climatic changes in southwest Europe in relation to the influence of the North Atlantic Ocean. Philosophical Transactions of the Royal Society of London. B, Biological Sciences, 318, pp.451-485. doi: https://doi.org/10.1098/rstb.1988.0019

Turon, J.L., 1984. Le palynoplancton dans l'environnement actuel de l'Atlantique nordoriental. Evolution climatique et hydrologique depuis le dernier maximum glaciaire. Mem. Inst Geol. Bassin Aquitaine, 17, pp.1-313.

Turon, J.L., Lézine, A.M. and Denèfle, M., 2003. Land-sea correlations for the last glaciation inferred from a pollen and dinocyst record from the Portuguese margin. Quaternary Research, 59, pp.88-96. doi: https://doi.org/10.1016/S0033-5894(02)00018-2

Tzedakis, P.C., 2007. Seven ambiguities in the Mediterranean palaeoenvironmental narrative. Quaternary Science Reviews, 26, pp.2042-2066. doi: https://doi.org/10.1016/J.QUASCIREV.2007.03.014

Tzedakis, P.C., Roucoux, K.H., de Abreu, L. and Shackleton, N.J., 2004. The duration of forest stages in southern Europe and interglacial climate variability. Science, 306, pp.2231-2235. doi: https://doi.org/10.1126/science.1102398

van der Brink, L.M., and Janssen, C.R., 1985. The effect of human activities during cultural phases on the development of montane vegetation in the Serra da Estrela, Portugal. Review of Palaeobotany and Palynology, 44, pp.193-215. doi: https://doi.org/10.1016/0034-6667(85)90016-8

van der Hammen, T., 1971. The floral record of the late Cenozoic of Europe. Late Cenozoic 
glacial ages, pp.391-424.

van der Knaap, W.O. and van Leeuwen, J.F.N., 1995. Holocene vegetation succession and degradation as responses to climatic change and human activity in the Serra de Estrela, Portugal. Review of Palaeobotany and Palynology, 89, pp.153-211. doi: https://doi.org/10.1016/0034-6667(95)00048-0

van der Schriek, T., Passmore, D.G., Franco Mugica, F., Stevenson, A.C., Boomer, I. and Rolaõ, J., 2008. Holocene palaeoecology and floodplain evolution of the Muge tributary, Lower Tagus Basin, Portugal. Quaternary International, 189, pp.135-151. doi: https://doi.org/10.1016/j.quaint.2007.09.007

van der Schriek, T., Passmore, D.G., Rolão, J. and Stevenson, A.C., 2007. Estuarine-fluvial floodplain formation in the Holocene Lower Tagus valley (Central Portugal) and implications for Quaternary fluvial system evolution. Quaternary Science Reviews, 26, pp.2937-2957. doi: https://doi.org/10.1016/J.QUASCIREV.2007.07.020

van Leeuwaarden, W. and Janssen, C.R., 1985. A preliminary palynological study of peat deposits near an oppidum in the Lower Tagus Valley, Portugal. Actas da I reunião do Quaternário Ibérico, 2, pp.225-236.

Villanueva, J. and Grimalt, J.O., 1996. Pitfalls in the chromatographic determination of the alkenone U37k index for paleotemperature estimation. Journal of Chromatography $A$, 723, pp.285-291. doi: https://doi.org/10.1016/0021-9673(95)00471-8

Villanueva, J., Grimalt, J.O., Cortijo, E., Vidal, L. and Labeyriez, L., 1997. A biomarker approach to the organic matter deposited in the North Atlantic during the last climatic cycle. Geochimica et Cosmochimica Acta, 61, pp.4633-4646. doi: https://doi.org/10.1016/S0016-7037(97)83123-7

Villanueva, J., Pelejero, C. and Grimalt, J.O., 1997a. Clean-up procedures for the unbiased estimation of C37 alkenone sea surface temperatures and terrigenous n-alkane inputs in paleoceanography. Journal of Chromatography $A, 757$, pp.145-151. doi: https://doi.org/10.1016/S0021-9673(96)00669-3

Vis, G.J., Kasse, C, Kroon, D, Vandenberghe, J, Jung, S, Lebreiro, SM \& Rodrigues, T 2016, Time-integrated 3D approach of late Quaternary sediment-depocenter migration in the Tagus depositional system: From river valley to abyssal plain. Earth-Science Reviews, 153, pp.192-211. doi: https://doi.org/10.1016/j.earscirev.2015.11.002

Vis, G.J., Kasse, C. and Vandenberghe, J., 2008. Late Pleistocene and Holocene palaeogeography of the Lower Tagus Valley (Portugal): effects of relative sea level, valley morphology and sediment supply. Quaternary Science Reviews, 27, pp.16821709. doi: https://doi.org/10.1016/j.quascirev.2008.07.003

Vis, G.J., Kasse, C., Kroon, D., Jung, S., Zuur, H. and Prick, A., 2010. Late Holocene sedimentary changes in floodplain and shelf environments of the Tagus River 
(Portugal). Proceedings of the Geologists Association, 121, pp.203-217. doi: https://doi.org/10.1016/j.pgeola.2009.12.003

Walker, M., Head, M.J., Berkelhammer, M., Björck, S., Cheng, H., Cwynar, L., Fisher, D., Gkinis, V., Long, A., Lowe, J. and Newnham, R., 2018. Formal ratification of the subdivision of the Holocene Series/Epoch (Quaternary System/Period): two new Global Boundary Stratotype Sections and Points (GSSPs) and three new stages/subseries. Episodes, 41, pp.213-223.

Weaver, P.P.E., 2003. Discovery Cruise 249, 19 Aug-10 Sep 2000. History of Sedimentation in the Gulf of Cadiz: investigations with the SOC giant piston corer, Southampton. Oceanography Centre, Southampton, UK.

Whittaker, R.J. and Fernández-Palacios, J.M., 2007. Island biogeography: ecology, evolution, and conservation. Oxford University Press.

\section{Figure captions:}

Figure 1. Location of the study area on the SW Iberian margin, showing (a) annual precipitation (Pann) distribution for the Iberian Peninsula (Fick and Hijmans, 2017) and the location of marine cores D13882 (this study, red circle), MD03-2697 (Naughton et al., 2007) and MD95-2043 (Fletcher and Sanchez Goñi, 2008), ODP 796 (Combourieu-Nebout et al., 2009), as well other continental records mentioned in the text: Lago de Ajo (Allen et al., 1996); La Roya (Allen et al., 1996); PRD-4 (López-Merino et al., 2012); Sanabria (Turner and Hannon, 1988; Allen et al., 1996); Ayoó de Vidrilaes (Morales-Molino and García-Antón, 2014); Quintanar de la Sierra 2 (Penalba, 1994); Lagoa comprida 2 (van der Brink and Janssen, 1985); Charco da Candieira (van der Knaap and van Leeuwen, 1995); El Maillo (Morales-Molino et al., 2013); CM5 (Fletcher et al., 2007), Siles (Carrión, 2002) and Sierra de Baza (Carrión et al., 2007). (b) Enlarged area showing SW Iberian margin and nearby cores, marine: MD95-2042 (Chabaud et al., 2014); U1385A (Oliveira et al., 2018); SU81-18 (Turon et al., 2003; Turon, 1984); and continental: Paul do Boquilobo (Vis et al., 2010); Alpiarça (van Leeuwarden and Jansen, 1985); Lagoa Travessa (Mateus, 1989; 1992); LSA Lagoa de Santo Andre (Santos and Sánchez Goñi, 2003); Barbarroxa de Baixo (Queiroz, 1999).

Figure 2. Chronology for marine core D13882, showing Bayesian deposition model based on 25 AMS radiocarbon dates (Naughton et al., 2019). The temporal resolution of the pollen record varies from multi-decadal (mean value of 30 years during the end of the last glacialinterglacial transition and last $2000 \mathrm{cal} \mathrm{yr} \mathrm{BP)} \mathrm{to} \mathrm{centennial} \mathrm{(mean} \mathrm{value} \mathrm{of} 220$ years from 11450 to $2100 \mathrm{cal} \mathrm{yr} \mathrm{BP}$ ), reflecting the trends in sedimentation rate (maximum values of 
$1254 \sim 370 \mathrm{~cm} / \mathrm{kyr}$ in the last glacial-interglacial transition and last $2000 \mathrm{cal} \mathrm{yr}$ BP, average 295 $1255 \mathrm{~cm} / \mathrm{kyr})$.

1257 Figure 3. Pollen diagram for core D13882, showing (a) conifers, temperate forest, carr, 1258 Mediterranean forest and heathland taxa, and (b) dry shrublands, steppic plants, Asteraceae and other herbs, wetland, aquatic plants and ferns with CONISS zonation.

Figure 4. Multiproxy data for site D13882, showing (a) alkenone-derived Sea Surface Temperatures (SST); pollen percentages for the main ecological pollen-based groups: (b) PIN (pinewoods); (c) TF (Temperate forest); (d) MF (Mediterranean forest); (e) ERI (heathlands); (f) STE (steppic/xerophytic plants). The stratigraphic division of the Holocene epoch (i.e. Early/Middle/Late subepochs, corresponding to the Greenlandian, Northgrippian and Meghalayan Ages) follows the formal recommendations of the International Commission on Stratigraphy (Walker et al., 2018).

Figure 5. Comparison of select ecological pollen-based groups (TMF, TF, MF, ERI and STE), for northwest - MD03-2697 (Naughton et al., 2007), southwest - D13882 (this study) and southeast IP - MD95-2043 (Fletcher and Sanchez Goñi, 2008), considering the (a) 11, (b) 9, (c) 6 and (d) 3 ka slice time. The percentages were calculated using a 1000 years bin, centred at the age considered (e.g. for $11 \mathrm{ka}$, all the samples between 11.5 and $10.5 \mathrm{ka}$ ).

Figure 6. North to south pattern of major forest changes across the Holocene, showing: a) Northern Hemisphere summer insolation $\left(65^{\circ} \mathrm{N}\right.$ Jun), the precession index and corresponding perihelion season (Berger, 1978); TMF curves (with the TF and MF components shown in green and orange, respectively) in marine cores (b) MD03-2697 (Naughton et al., 2007), (c) D13882 (this study), (d) MD95-2043 (Fletcher and Sanchez Goñi, 2008). The stratigraphic division of the Holocene follows the ICS stratigraphy (Walker et al., 2018).

1282

Table caption:

Table 1. Pollen zone description for marine core D13882. 
Table 1. Pollen zone description for marine core D13882.

\begin{tabular}{|c|c|c|c|}
\hline $\begin{array}{l}\text { Pollen } \\
\text { Zone }\end{array}$ & $\begin{array}{l}\text { Depth range } \\
\text { (cm) }\end{array}$ & $\begin{array}{l}\text { Age Range } \\
\text { (cal yr BP) }\end{array}$ & Pollen signature \\
\hline D13882-7 & $400-20$ & $1970-640$ & $\begin{array}{l}\text { Decrease of TF and MF together with } \\
\text { Pinus percentages. TF and Pinus recover } \\
\text { during the first part while MF persists } \\
\text { (values around } 5 \% \text { ). Peak values of } \\
\text { Ericaceae (peaks up to } \sim 60 \% \text { ). Increase } \\
\text { in Asteraceae group, carr (Alnus } \sim 5 \% \text { ), } \\
\text { wetland, aquatics (Isoetes } \sim 10 \% \text { ) and a } \\
\text { minor increase in steppic plants. } \\
\text { Persistence of anthropic pollen markers: } \\
\text { Vitis, Olea, Plantago lanceolata and } \\
\text { increase of Poaceae }>40 \mu \mathrm{m} .\end{array}$ \\
\hline D13882-6 & $580-400$ & $4770-1970$ & $\begin{array}{l}\text { Increase and stabilisation of heathland as } \\
\text { the dominant group ( } 50 \% \text {, w/ mainly } \\
\text { Ericaceae undiff., Erica australis and Erica } \\
\text { umbellata) at the expense of TF }(\sim 20 \%) \\
\text { and MF }(\sim 5 \%) \text {; slight increase of dry } \\
\text { shrublands and ferns; carr development. } \\
\text { The appearance of anthropic indicators: } \\
\text { Junglans, Vitis and Linum. }\end{array}$ \\
\hline D13882-5 & $670-580$ & $7360-4770$ & $\begin{array}{l}\text { A marked drop in TF, MF and Pinus; } \\
\text { increase in heathland; slight recovery of } \\
\text { dry shrublands, Asteraceae, wetland, } \\
\text { aquatic plants and ferns. Minor peaks in } \\
\text { Artemisia and Amaranthaceae (values } \sim 8- \\
10 \% \text { ). }\end{array}$ \\
\hline D13882-4 & $708.5-670$ & $9760-7360$ & $\begin{array}{l}\text { Peak values for TF (average } \sim 50 \% \text {, peak } \\
\text { Quercus deciduous type }>60 \% \text { ) with a } \\
\text { continuous increase of MF (peak value }\end{array}$ \\
\hline
\end{tabular}


$\sim 30 \%$ ); Decrease of Asteraceae (< 5\%) and a minor decrease in steppic plants, wetland and aquatics.

Recovery of TF (up to $\sim 50 \%$ ) as well as D13882-3 804.5 - $708.5 \quad 11790$ - $9760 \quad$ MF (peak of Quercus evergreen type up to $\sim 28 \%$ ); decrease of heathland (average < $\sim 5 \%$ ), reduction of dry shrublands, Asteraceae and steppic plants (average < $5 \%$ ); marked increase of aquatics (up to $\sim 10 \%$ ) accompanied by a small increase of wetland taxa $(\sim 10 \%)$ and ferns $(<\sim 5 \%)$.

Dominance of steppic plants and D13882-2 $1131-804.5 \quad 12890$ - Asteraceae (each group 30\%); peak 11790 frequencies of Pinus ( 75\%) accompanied by Cedrus and Cupressaceae (both $<\sim 5 \%)$; consistent/persistent TF ( 30\%) increasing towards the end of the zone; wetland taxa ( 10\%); heathland development ( $10 \%$, peaking $\sim 25 \%$ ); MF generally low reaching minimum values $(\sim 2 \%)$ and recovering by the end of the zone $(\sim 10 \%)$.

D13882-1 $1191-1131 \quad 13260$ - Dominance of MF ( 20\%) and Asteraceae 12890 (mainly Centaurea scabiosa type and Taraxacum type, $\sim 25 \%$ ); minor increase of wetland group $(\sim 5 \%)$ and steppic plants (average $\sim 15 \%$ ); slight decrease of TF (average $\sim 15 \%$ ) and Pinus ( 55\%). 
Figure 1

a)

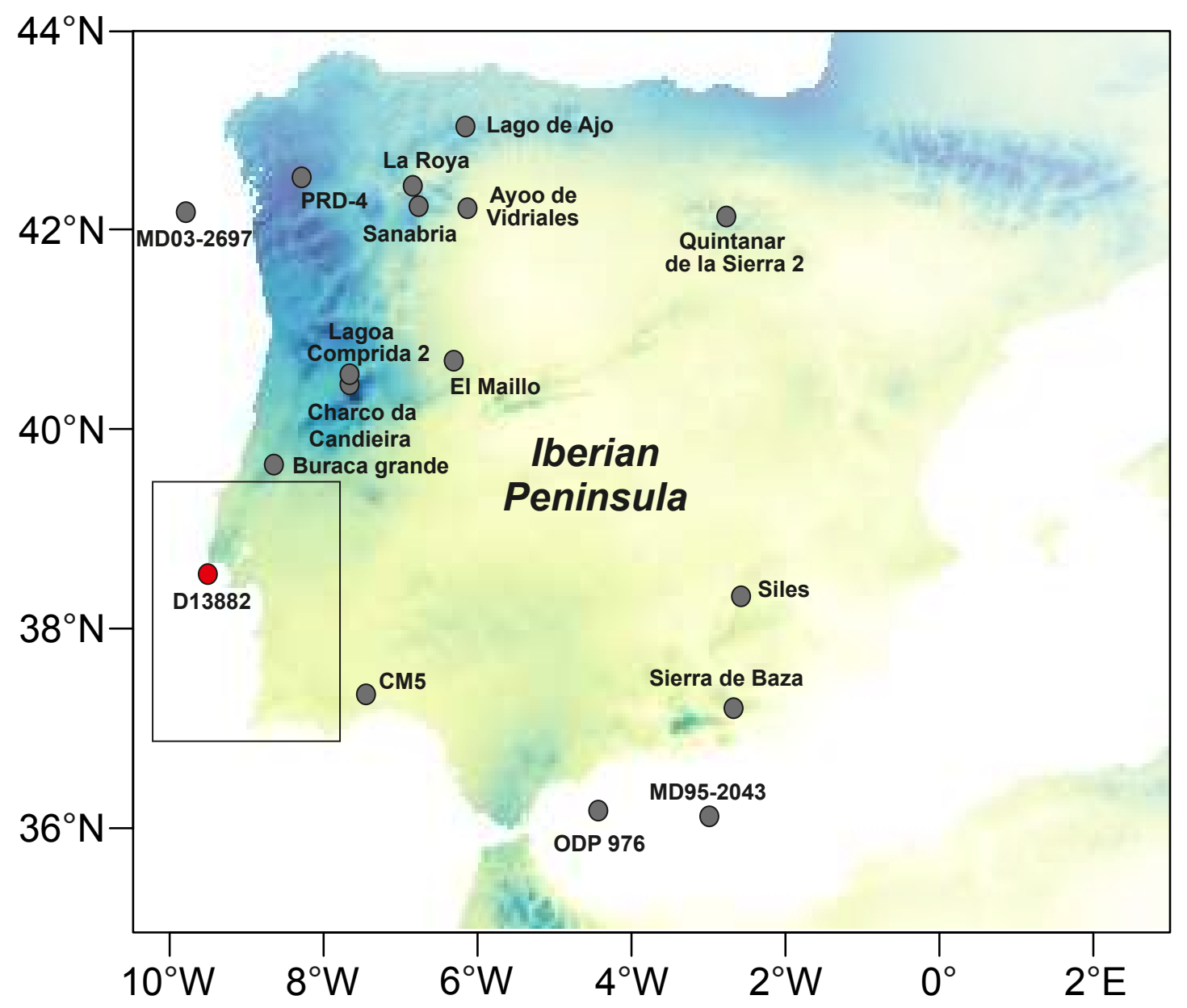

\section{PANN (mm/yr)}

1600

1400

1200

1000

$-800$

$-600$

$-400$

b)

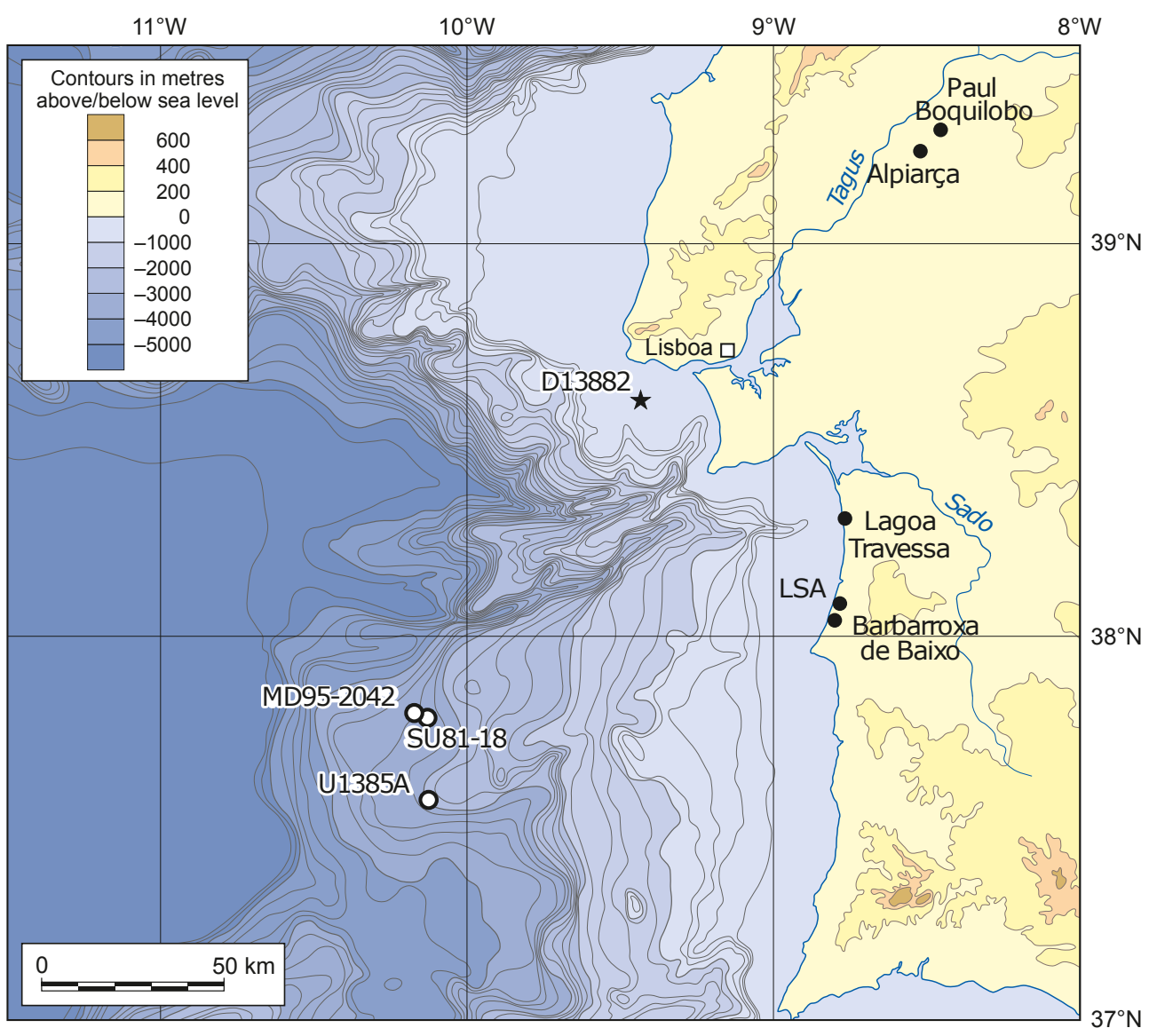


Figure 2

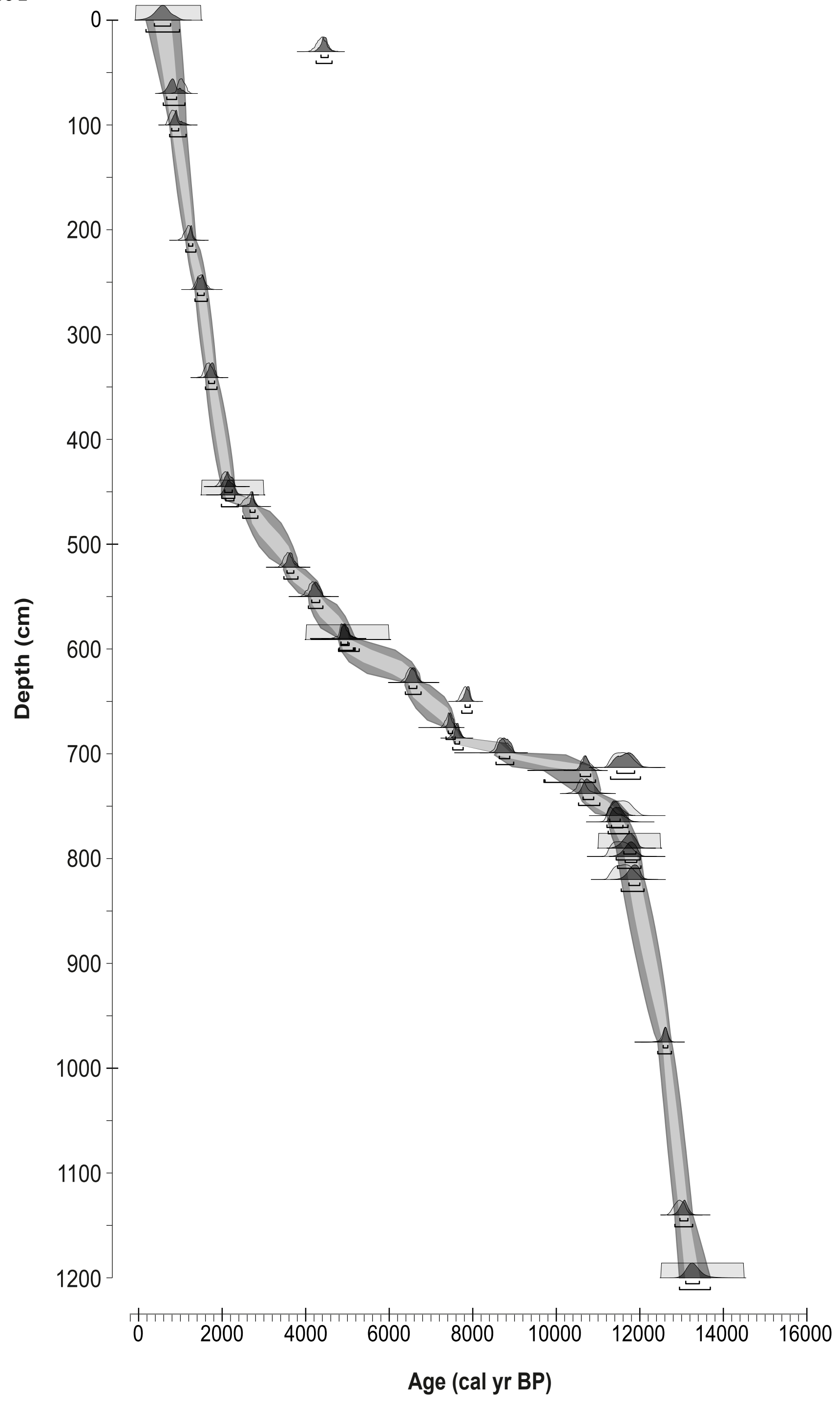




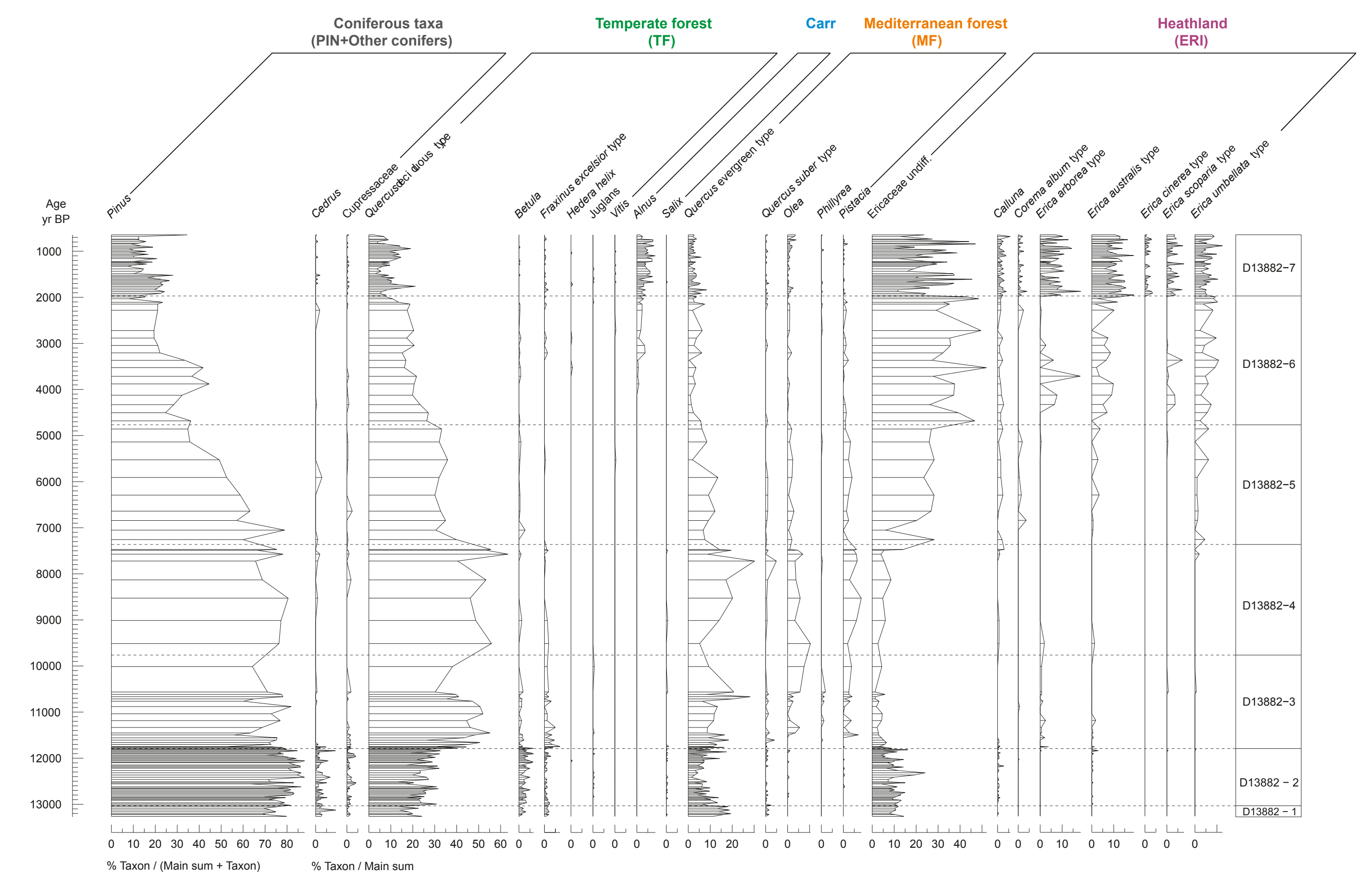



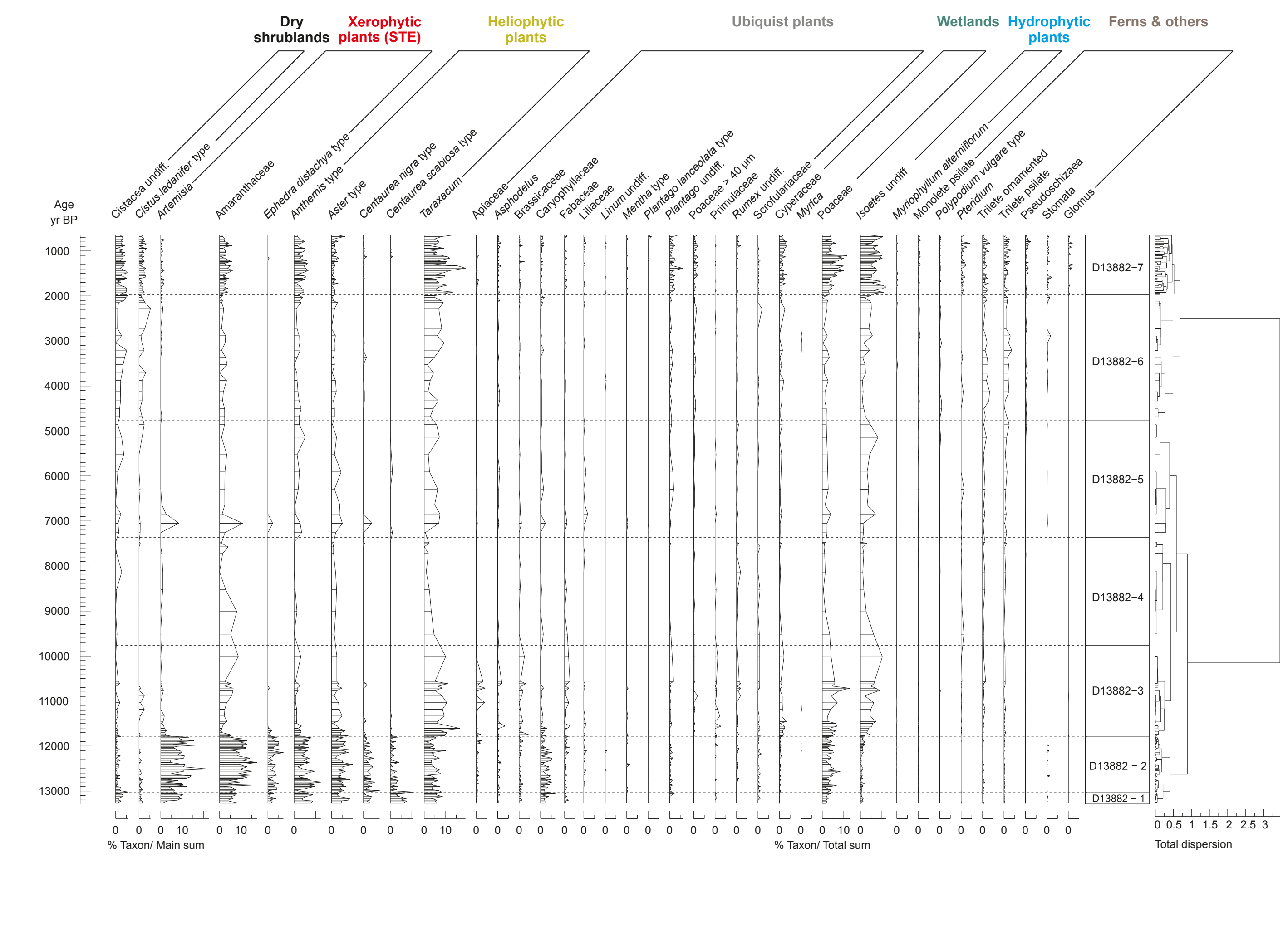

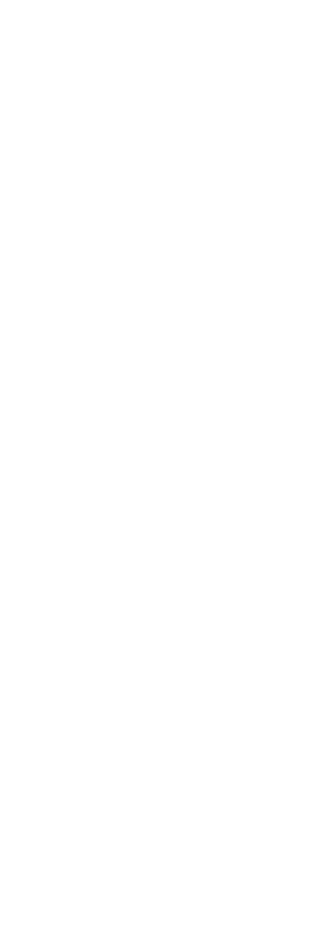


Age (cal yr BP)

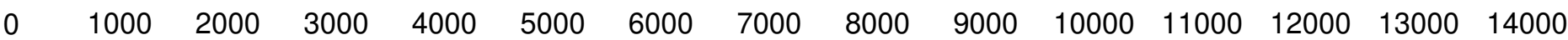

a)
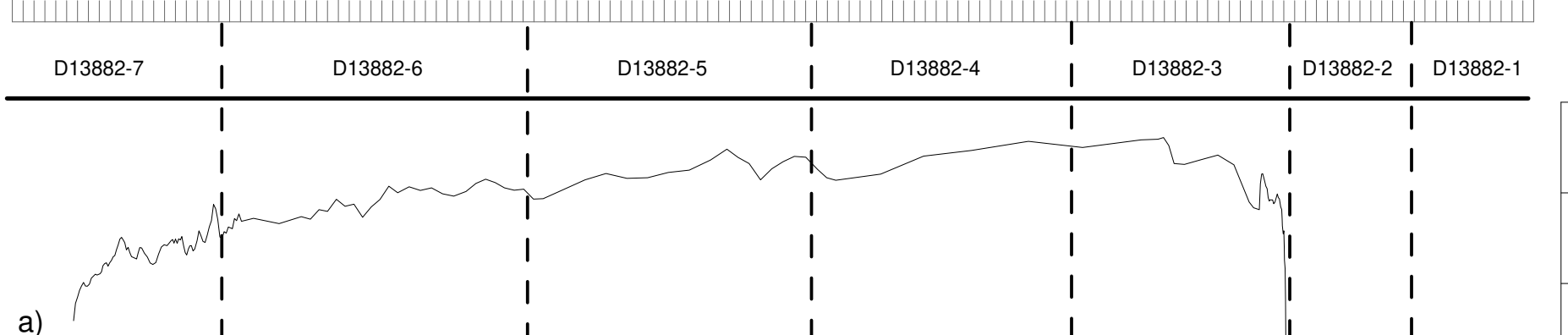

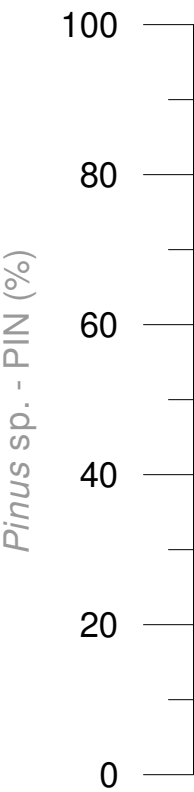

b)

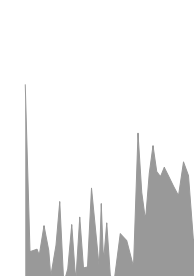

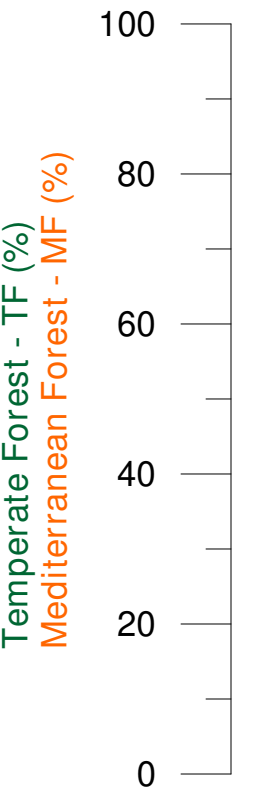

c)

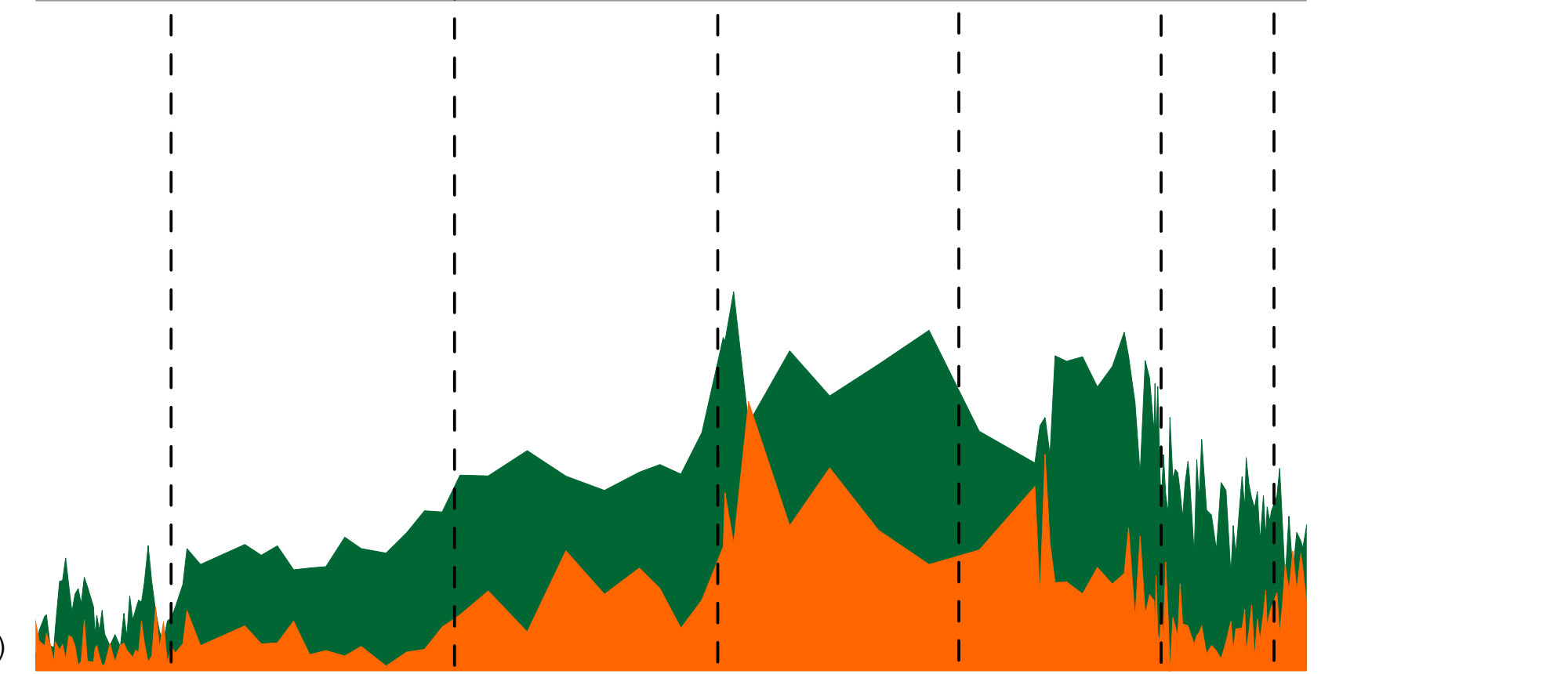

$\left.\begin{array}{c}100 \\ 80 \\ 60 \\ 0 \\ 20 \\ 0 \\ 0\end{array}\right]$

d)

e)
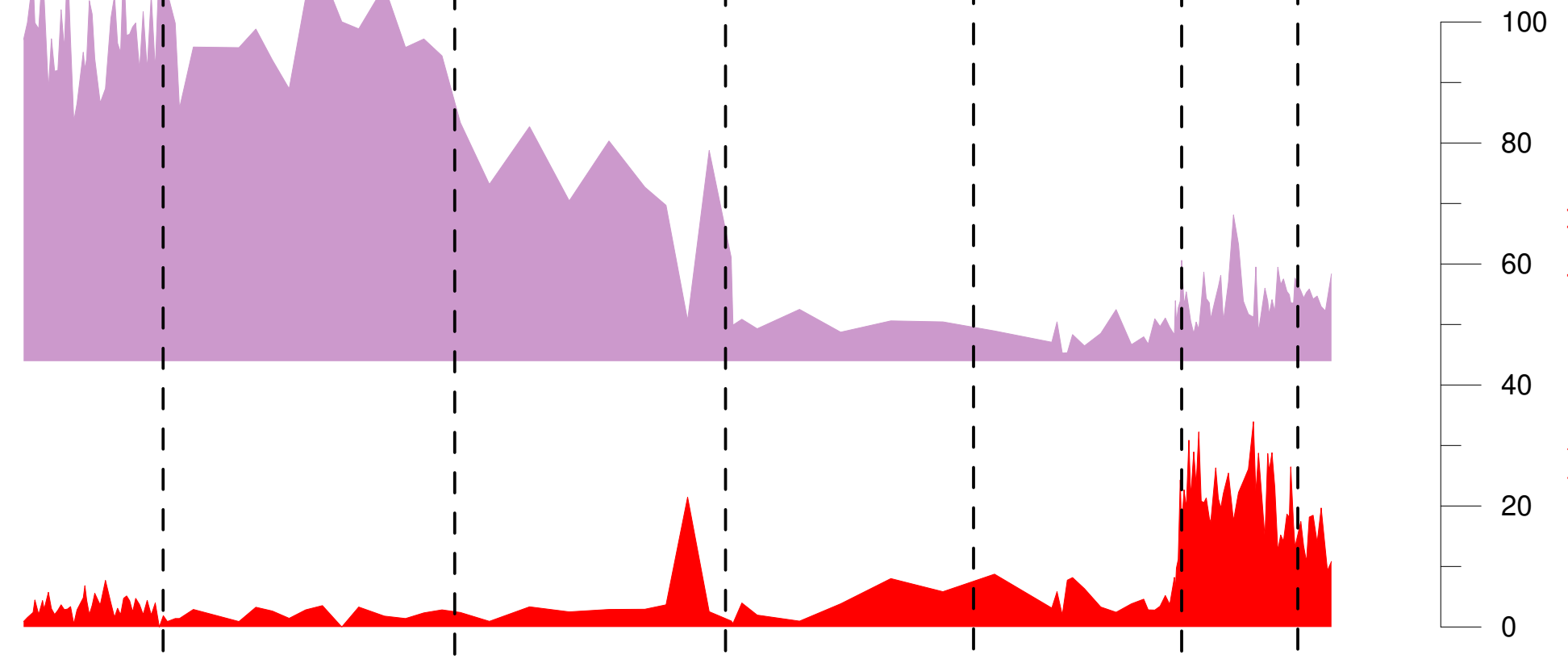

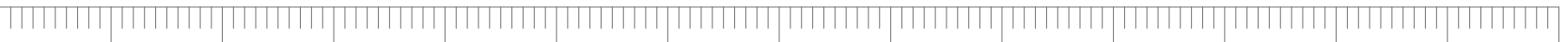

$\begin{array}{llllllllllllll}1000 & 2000 & 3000 & 4000 & 5000 & 6000 & 7000 & 8000 & 9000 & 10000 & 11000 & 12000 & 13000 & 14000\end{array}$ Age (cal yr BP) 
a) 100

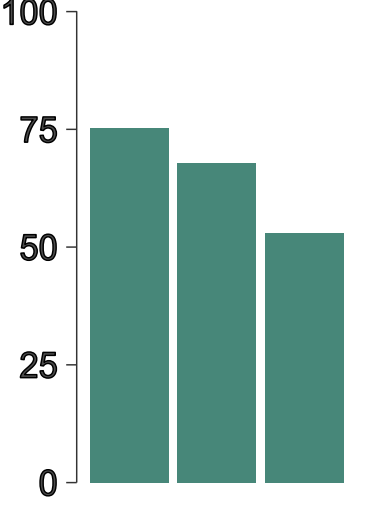

b) 100

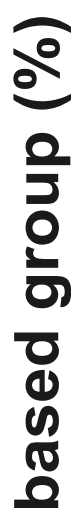

음

c) 100
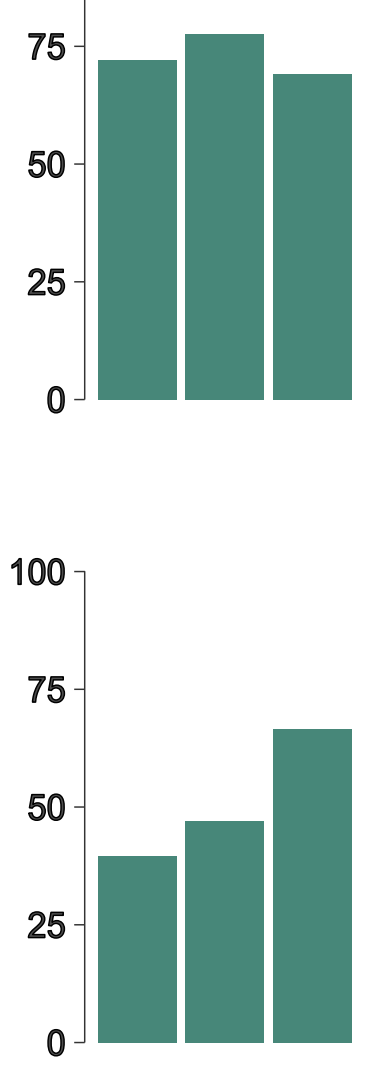

TF

MF

$11 \mathrm{ka}$
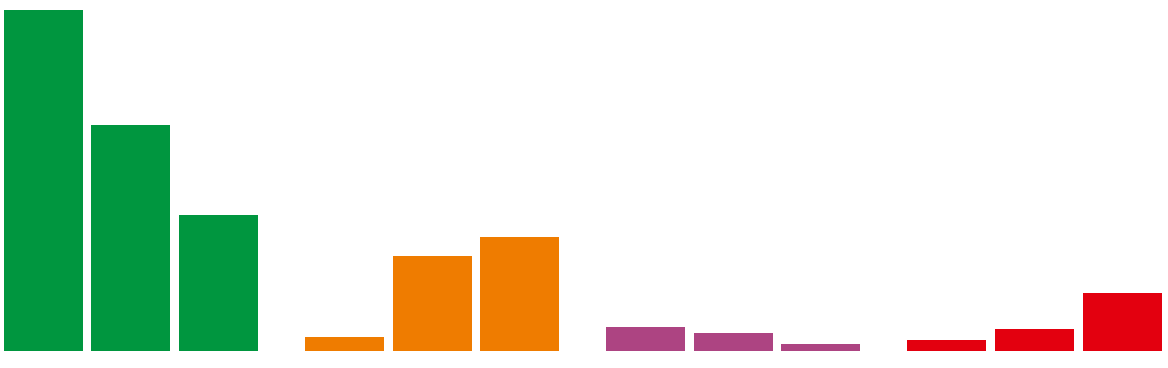

9 ka
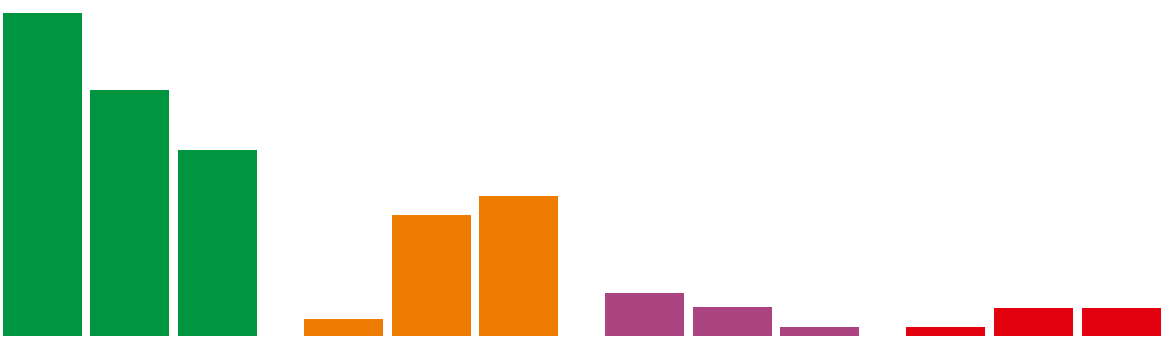

$6 \mathrm{ka}$
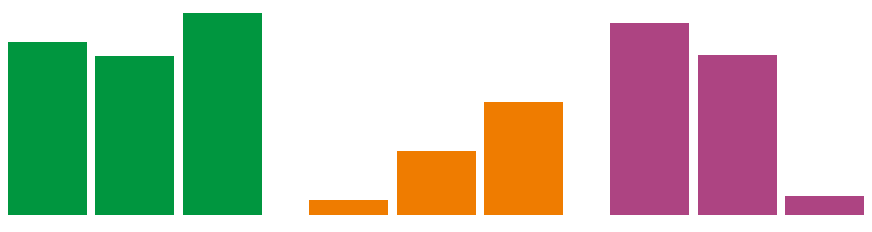

3 ka

d) 100
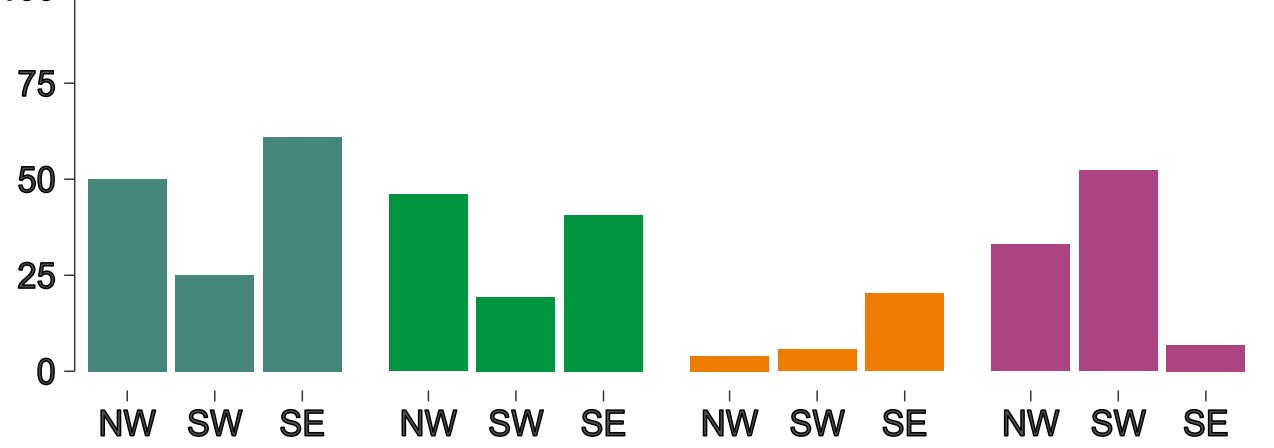

NW SW SE

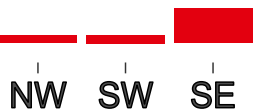


Age (cal yr BP)

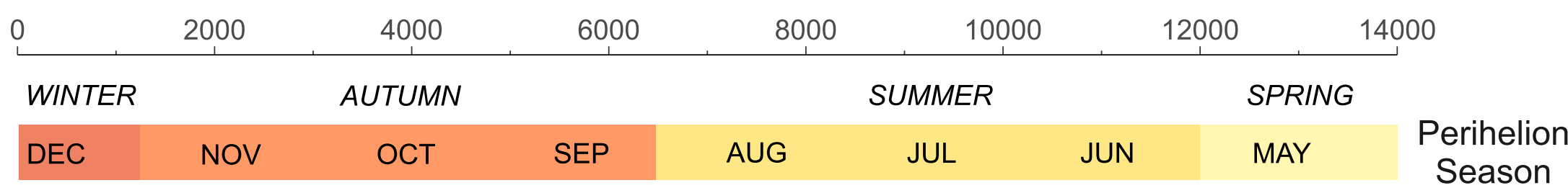

a)

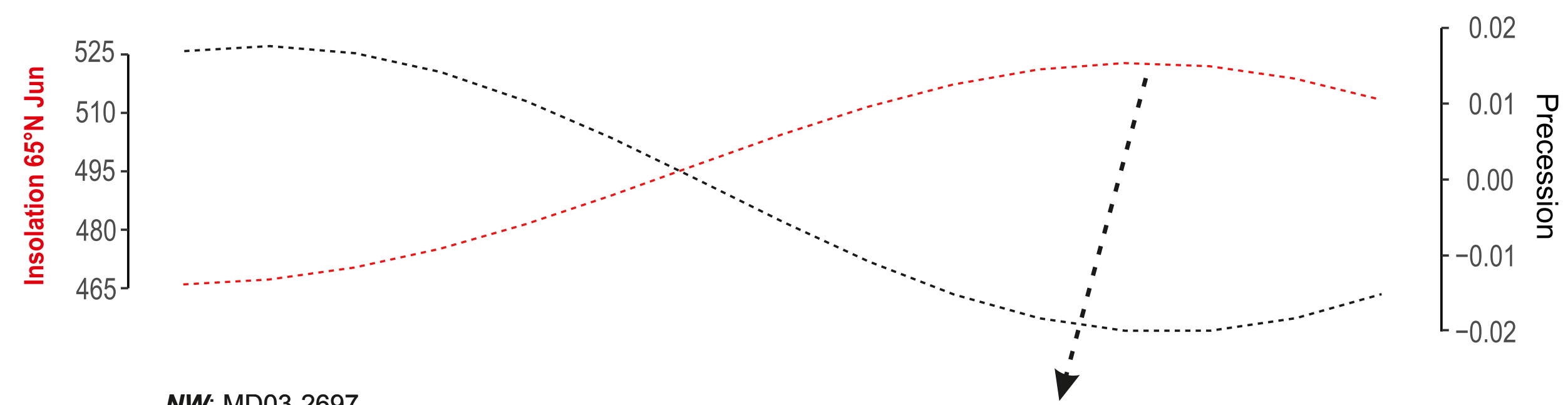

b)

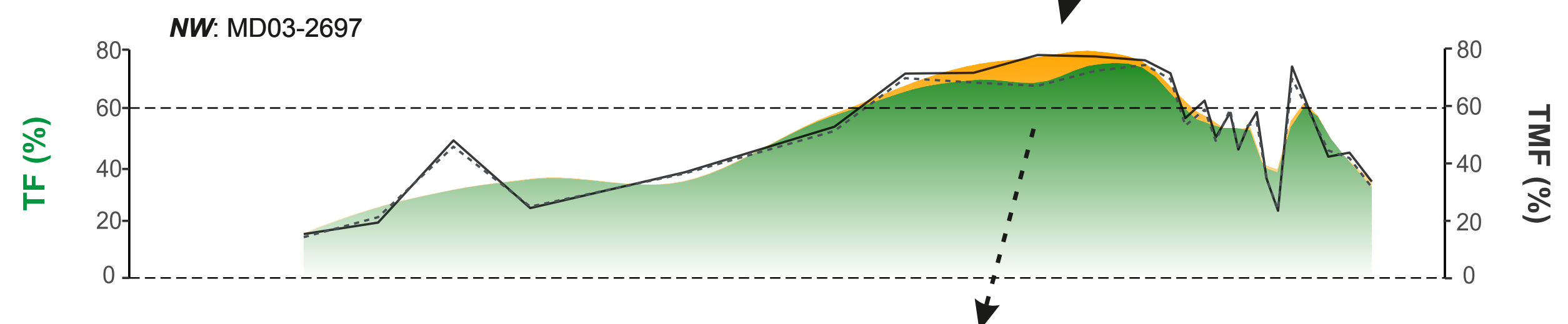

c)

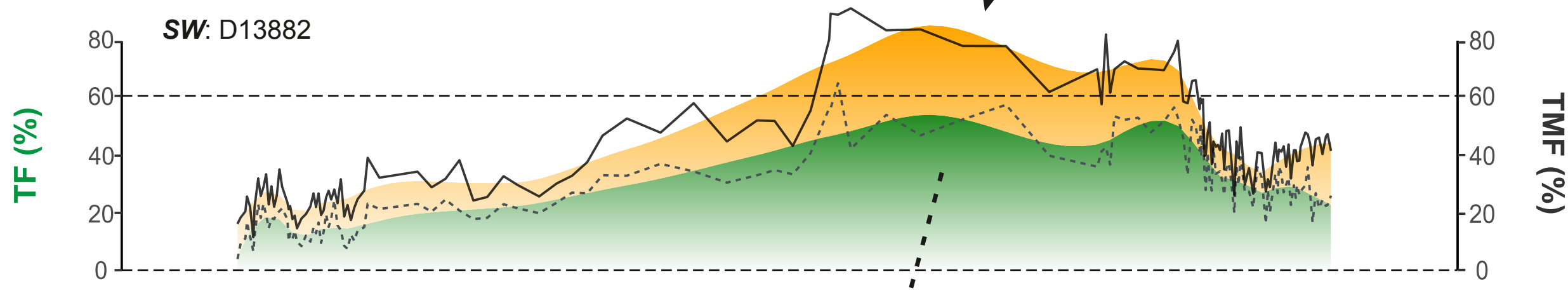

d)

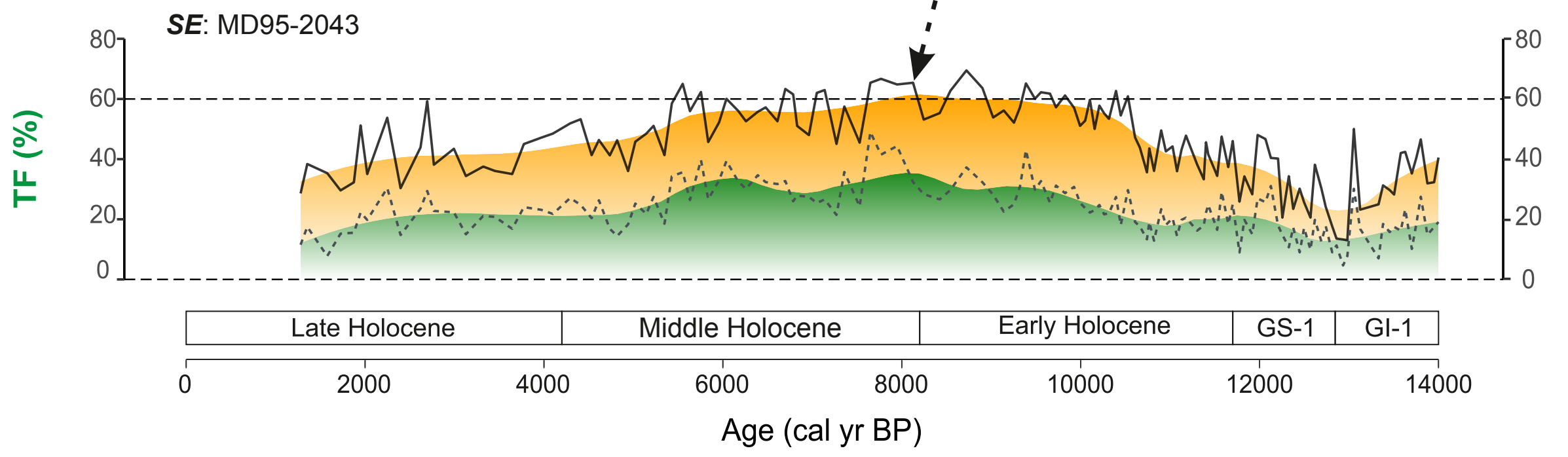

궁 
Click here to access/download RDM Data Profile XML DataProfile_4766658.xml 